\title{
Phenyl Substituted Porphyrins. 6. Acylation of Alcohols with Carboxyphenylporphyrins
}

\author{
Mariya A. Salnikova, ${ }^{a}$ Tatiana V. Lubimova, ${ }^{\text {b }}$ Sergei A. Syrbu, ${ }^{a}$ \\ and Alexander S. Semeikin ${ }^{@}$ \\ ${ }^{a}$ Research Institute of Macroheterocycles, Ivanovo State University of Chemistry and Technology, 153000 Ivanovo, Russia \\ ${ }^{\mathrm{b}}$ Institute of Solution Chemistry, Russian Academy of Sciences, 153045 Ivanovo, Russia \\ @Corresponding authorE-mail: semeikin@isuct.ru
}

\begin{abstract}
Pyrrolic precursors and benzaldehydes were used to afford meso-carboxyphenylporphyrins bearing one or four carboxyl groups. The reaction conditions for the acylation of alcohols with the obtained carboxyphenylporphyrins in the presence of carbodiimides were studied. Optimal reaction conditions were found and a series of phenylporphyrin esters of various structure was synthesized.
\end{abstract}

Keywords: Porphyrins, acylation, perfluorinated alcohols, 1-(3-dimethylaminopropyl)-3-ethylcarbodiimide hydrochloride (EDAC), 4-dimethylaminopyridine (DMAP).

\section{Фенилзамещенные порфирины. 6. Ацилирование спиртов карбоксифенилпорфиринами}

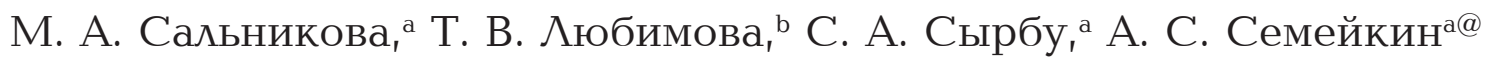 \\ ${ }^{a}$ НИИ Макрогетероциклических соединений, Ивановский государственный химико-технологический университет, \\ 153000 Иваново, Россия \\ ${ }^{\mathrm{b}}$ Институт химии растворов РАН, 153045 Иваново, Россия \\ @E-mail: semeikin@isuct.ru
}

\begin{abstract}
Из пиррольных предшественников и бензальдегидов синтезированы мезо-карбоксифенилпорфирины, содержащче одну или четыре карбоксильные группь. Изучены условия ацилирования спиртов полученными карбоксифенилпорфиринами в присутствии карбодиимидов. Найдень оптимальные условия проведения реакции, и синтезирован ряд сложных эфиров фенилпорфиринов различной структуры.
\end{abstract}

Ключевые слова: Порфирины, ацилирование, перфторированные спирты, 1-(3-диметиламинопропил)-3этилкарбодиимид гидрохлорид (EDAC), 4-диметиламинопиридин (DMAP).

\section{Introduction}

meso-Substituted porphyrins bearing active groups in phenyl substituents present a considerable interest in the aspect of using them as basis for more complex conjugates in order to study the influence of substituents on the properties of the porphyrin core.

Previously we have described the procedures for acylation of hydroxy ${ }^{[1]}$ and aminopheny ${ }^{[2]}$ porphyrins with carbonic acids and the synthesis of tetraphenylporphyrin fluoroalkyl derivatives. ${ }^{[3]}$ Here we present the study of the specifics of alcohols acylation with carboxyphenyl porphyrins resulting in the formation of esters.

Various methods of acylation of amino ${ }^{[4-11]}$ and hydroxyl compounds ${ }^{[12-15]}$ with carboxyphenylporphyrins have been published. The acylation agents can be either the carboxyphenylporphyrins themselves in the presence of activators, ${ }^{[8-11,13-15]}$ or the corresponding chloroanhydrides. ${ }^{[4-7,12]}$ Acylation is conducted in methylene chloride, ${ }^{[6,9,10,13,14]}$ chloroform, ${ }^{[7,8]} \mathrm{THF}^{[15]} \mathrm{DMF}^{[11]}$ and other solvents with 
pyridine added..$^{[4,5,12]} \mathrm{DCC}^{[13,15]}$ or $\mathrm{EDAC}^{[9,10,14,15]}$ in the presence of DMAP are used as the condensing agents.

\section{Results and Discussion}

Firstly, we obtained a series of carboxyphenyl porphyrins of various nature, such as tetraphenylporphyrin derivatives bearing one $(\mathbf{5}, \mathbf{9})$ or four carboxyl groups $(\mathbf{1 1})$, as well as several $\beta$-octaalkyl substituted porphyrins (14). Carboxyphenylporphyrins [5 $\left.(\mathrm{X}=-), 5\left(\mathrm{X}=\mathrm{OCH}_{2}\right), 9\right]$ were obtained in the course of a "mixed aldehyde condensation". The presence of the carboxyl group does not allow the separation by chromatography, so the synthesis was conducted using the corresponding esters of carboxybenzaldehydes (2, 6) with the subsequent hydrolysis of the resulting esters [4
$(\mathrm{X}=-; \mathrm{R}=\mathrm{Me}), 8.1 \%$ yield; $4\left(\mathrm{X}=\mathrm{OCH}_{2} ; \mathrm{R}=\mathrm{Et}\right), 10 \%$ yield and $\mathbf{8}, 9.6 \%$ yield] (Schemes 1,2$)$.

Via the condensation of 3- and 4-carboxybenzaldehydes 10 with pyrrole $\mathbf{1}$ in a mixture of propionic acid with nitrobenzene, symmetrically substituted 5,10,15,20-tetrakis(3and 4-carboxyphenyl)porphines (11) were obtained with the yields of 55.6 and $43.0 \%$, correspondingly (Scheme 3 ).

A two-step one-pot procedure analogous to ${ }^{[16-18]}$ was employed to afford carboxyporphyrins 14 by the condensation of biladiene 12 with benzaldehydes $2(\mathrm{X}=-; \mathrm{R}=\mathrm{H}$ and $\mathrm{X}=\mathrm{OCH}_{2} ; \mathrm{R}=\mathrm{Et}$ ) in butanol and further hydrolysis of the obtained esters 13 (X=-; $\mathrm{R}=\mathrm{Me}$ and $\left.\mathrm{X}=\mathrm{OCH}_{2} ; \mathrm{R}=\mathrm{Bu}\right)$. The yields were $20.8 \%$ and $45.6 \%$, correspondingly (Scheme 4 ). It should be noted that in the course of the synthesis of the ester of carboxymethyleneoxyphenylporphyrin, interesterefication occurs and butyl ester $\mathbf{1 3}\left(\mathrm{X}=\mathrm{OCH}_{2} ; \mathrm{R}=\mathrm{Bu}\right)$ is obtained
4<smiles>c1cc[nH]c1</smiles>

1<smiles>O=Cc1ccc(C(=O)O)cc1</smiles>

2<smiles>O=Cc1ccccc1</smiles>

3

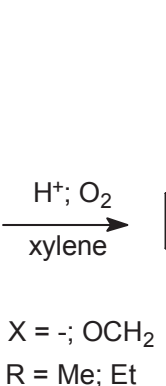

$\mathrm{Ph}$<smiles></smiles>

4<smiles></smiles>

5

Scheme 1.
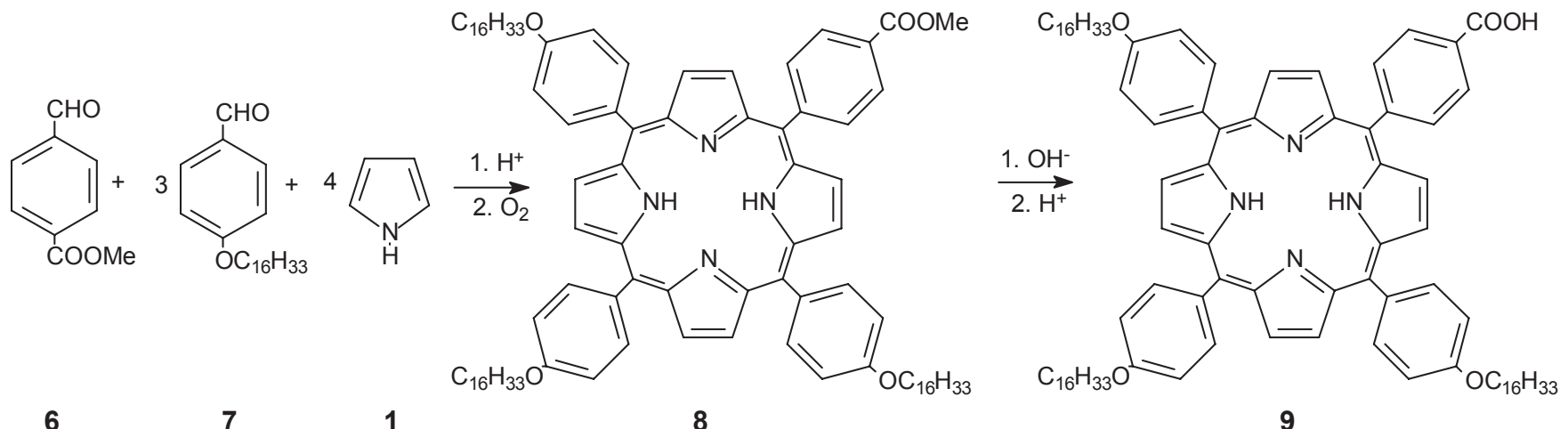

9

Scheme 2.

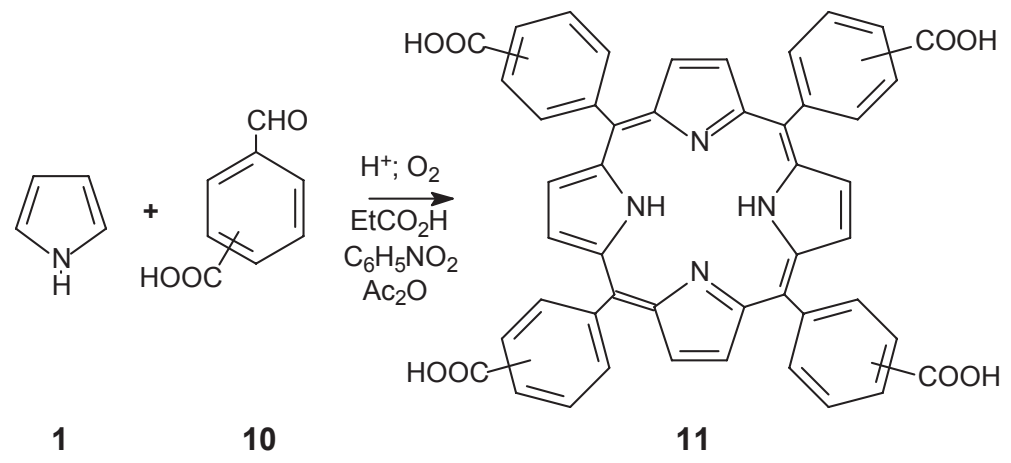

Scheme 3. 
<smiles>CC1=C(C)C(=Cc2[nH]c(CC3=[NH+]C(=Cc4[nH]cc(C)c4C)C(C)=C3[GaH])c(-c3ccccc3)c2C)N=C1</smiles>

12
2

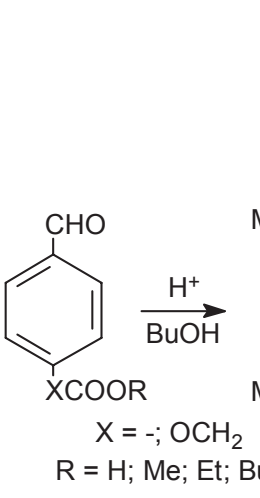

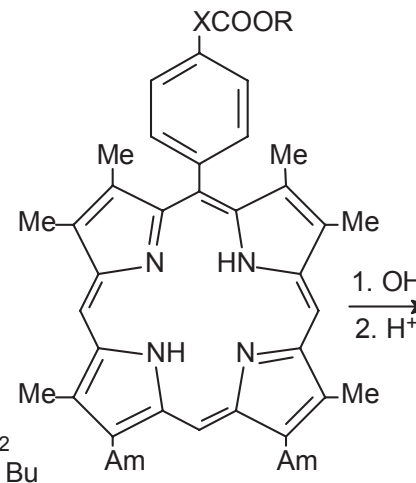

13

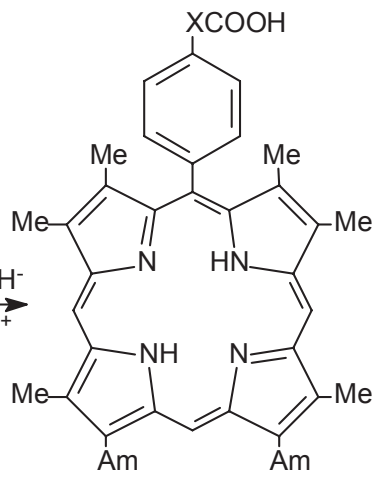

14

Scheme 4.

instead of the methyl one. When benzaldehyde 2 is used ( $\mathrm{X}=-$; $\mathrm{R}=\mathrm{H}$ ), esterification is insignificant and porphyrin $\mathbf{1 3}(\mathrm{X}=-$; $\mathrm{R}=\mathrm{Bu}$ ) is formed with $3.5 \%$ yield. However, for chromatographic purification the porphyrin $\mathbf{1 3}(\mathrm{X}=-; \mathrm{R}=\mathrm{H})$ was converted into its methyl ester $\mathbf{1 3}(\mathrm{X}=-; \mathrm{R}=\mathrm{Me})$. The obtained esters were then subjected to hydrolysis with almost quantitative yields of the target carboxyporphyrins 14 .

Acylation of alcohols with carboxyphenylporphyrins was carried out by a previously developed procedure ${ }^{[1,2]}$ with porphyrins being the acylating agents.

The specifics of acylation of $n$-perfluoro-1,1,9- $H$ nonyl alcohol with 5-(4-carboxyphenyl)-2,3,7,8,12,18hexamehtyl-13,17-di- $n$-amylporphyrin $14(\mathrm{X}=-)$, resulting in the formation of porphyrin 16 (Scheme 5) (Table 1) was studied. The reaction conditions appeared to be the same for
Table 1. Dependency of the yield of porphyrin $\mathbf{1 6}$ on the amount of $n$-perfluoro-1,1,9- $H$-nonyl alcohol, EDAC and DMAP.

\begin{tabular}{cccc}
\hline Alcohol (eq) & EDAC (eq) & DMAP (eq) & Yield, \% \\
\hline 1.1 & 2 & 0.6 & 50.8 \\
1.1 & 1.5 & 0.6 & 52.5 \\
1.5 & 1.5 & 0.6 & 54.6 \\
1.5 & 2 & 0.6 & 66.1 \\
1.5 & 1.1 & 0.6 & 33.5 \\
2 & 2 & 0.6 & 64.4 \\
1.5 & 1.5 & 1 & 47.2 \\
1.5 & 2 & 1 & 57.5 \\
1.5 & 2.5 & 0.6 & 65.7 \\
\hline
\end{tabular}

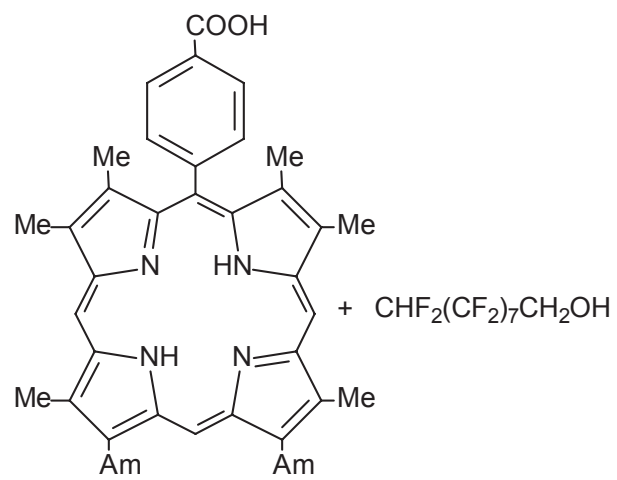<smiles>CC(=O)OCC(=O)OCC(F)(F)C(F)(F)F</smiles>

16

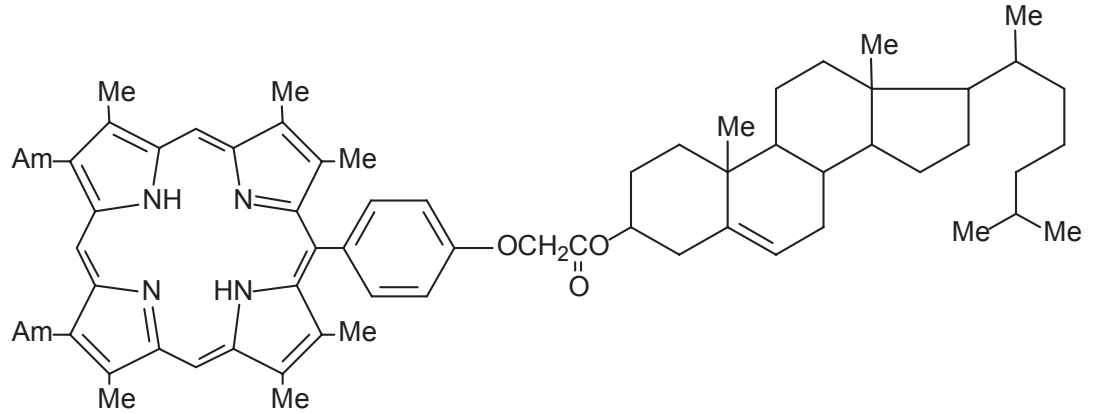


the acylation of aminophenylporphyrins with carbonic acids. ${ }^{[2]}$ Acylation of cholesterol with porphyrin $14\left(\mathrm{X}=\mathrm{OCH}_{2}\right)$ afforded a conjugate 18 (12\% yield).

This method was also used to convert $5(X=-)$ and 9 into porphyrins 17, bearing polyfluorinated substituents (Scheme 6). The yields were 63 and $45 \%$, correspondingly.

Porphyrins that may exhibit the properties of liquid crystals were synthesized. In three steps we obtained a porphyrin-cholesterol conjugate $\mathbf{1 9}$, which has a discotic and cholesteric residues linked by a long decamethylene spacer (Scheme 7). Alkylation of oxyphenylporphyrin 20 with methyl ester of 11-bromoundecanoic acid gives the ester 21 (84\% yield), which after alkaline hydrolysis affords carboxypophyrin 22 (67\% yield) and the reaction with cholesterol results in the target conjugate 19. The yield was $32 \%$, while using the corresponding chloroanhydride afforded only $13 \%$ yield.

In a similar way, the reaction of $\mathbf{2 2}$ with aminohenylporphyrin $\mathbf{2 3}$ was used to obtain a dimeric porphyrin 24 with $35 \%$ yield (Scheme 8 ).

While the symmetric compound 5,10,15,20-tetrakis(4-hexadecyloxyphenyl)porphine exhibits a monotropic liquid crystal phase that vitrifies preserving the meso-phase texture, polarization microscopy studies of the mesomorphic properties of unsymmetrical analogs showed that compound $\mathbf{2 0}$ is not mesomorphic. ${ }^{[3]}$

In order to study the discotic liquid crystal properties of porphyrins we synthesized symmetric porphyrins

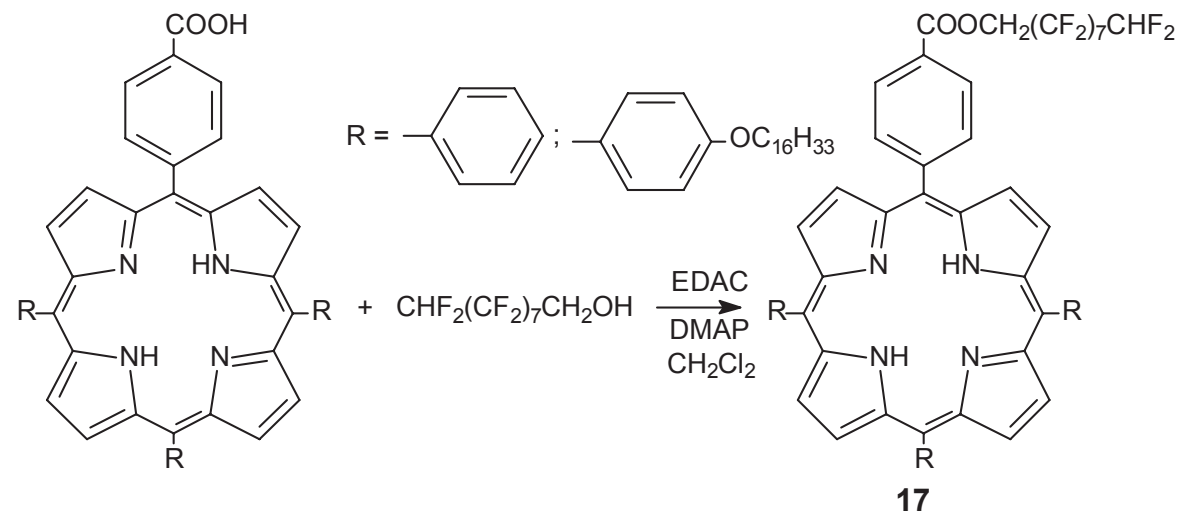

Scheme 6.<smiles>[R]Cc1ccc(C2=NC(=C([R])c3ccc([R])[nH]3)C=C2)[nH]1</smiles>

20

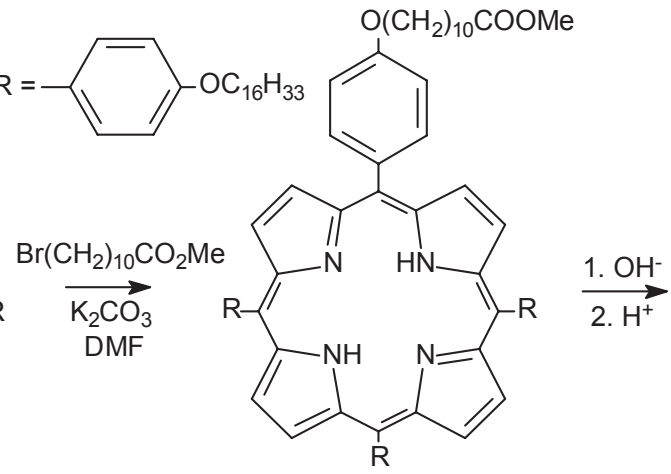

21

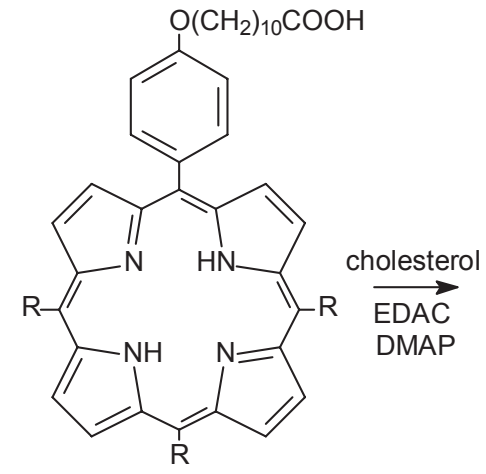

22

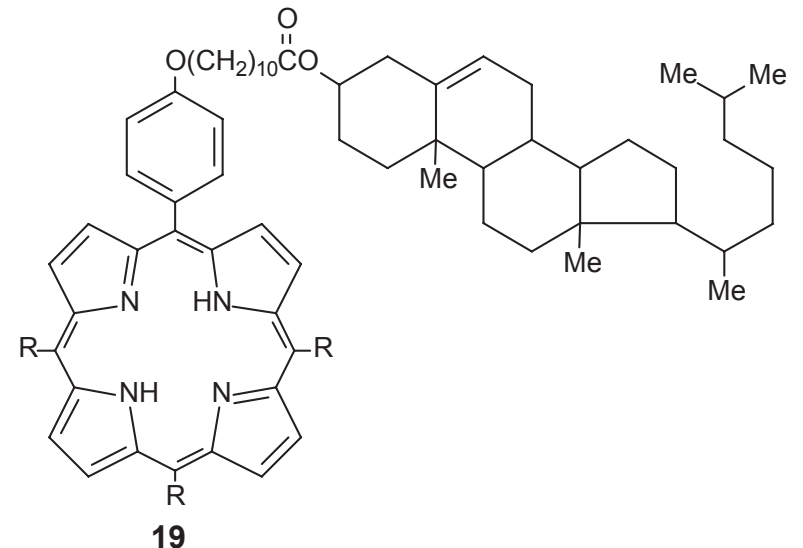

Scheme 7. 
<smiles></smiles>

22

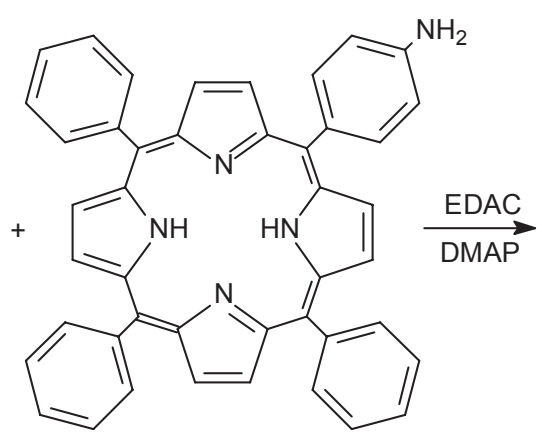

23

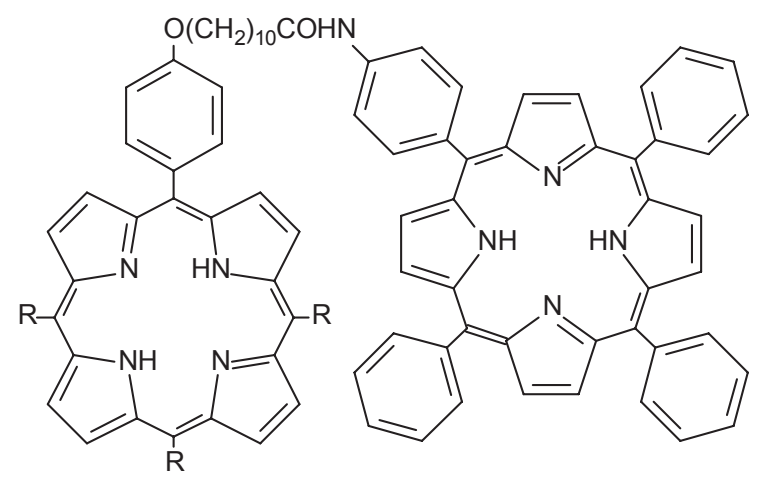

24

Scheme 8.

bearing ester groups with long-chain substituents of different nature (aliphatic and perfluorinated residues) 25, by the acylation of the corresponding alcohols with mesotetracarboxyphenylporphyrins 11 (Scheme 9) (Table 2).

The low yields of porphyrins $\mathbf{2 5}$ are caused, to our suggestion, by the complete insolubility if the starting carboxyphenylporphyrins in methylene chloride that hinders the formation of the intermediate $O$-acylureas. This assumption is confirmed by increased (by $\sim 6 \%$ ) yields when preliminary ultrasonic treatment of the starting compounds is performed. Moreover, the presence of four carboxyl groups leads to the formation of porphyrinic mixtures in which only the tetrasubstituted porphyrins are chromatographically mobile. ${ }^{[3]}$

Furthermore we conducted the synthesis of tetracarboxyporphyrin esters $\mathbf{2 5}$ by nucleophilic substitution of halogen in alkyl halides in DMF in the presence of potash, however the yields in this case are also low and the reaction proceeds slowly (Scheme 9).

All the obtained porphyrins were analyzed using a complex of spectral studies (UV-vis, IR and ${ }^{1} \mathrm{H}$ NMR spectroscopy) and their purity and identity were confirmed by TLC.

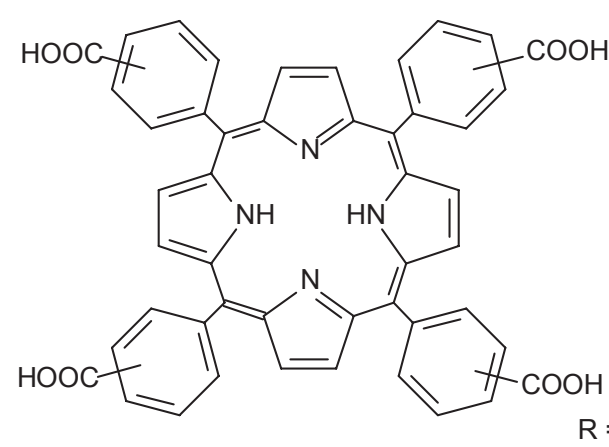

$\mathrm{R}=\left(\mathrm{CH}_{2}\right)_{\mathrm{n}} \mathrm{CH}_{3} \mathrm{n}=2-6$ $\mathrm{R}=\mathrm{CH}_{2}\left(\mathrm{CF}_{2}\right)_{\mathrm{n}} \mathrm{CHF}_{2} \mathrm{n}=1,7$

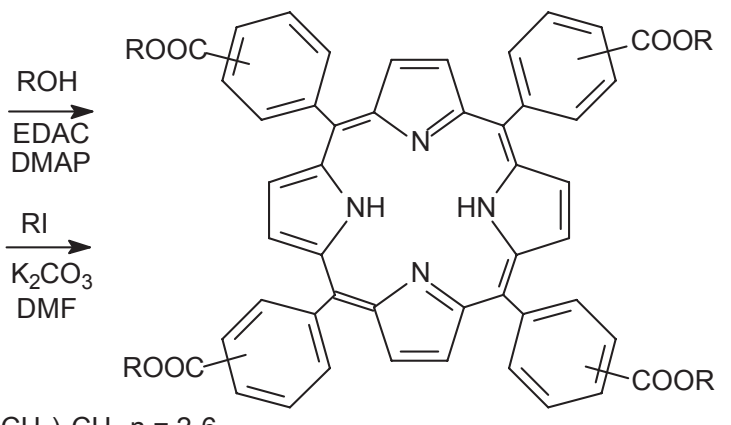

25

Scheme 9.

Table 2. Yields of the symmetrically substituted esters $\mathbf{2 5}$.

\begin{tabular}{ccc|ccc}
\hline \multicolumn{2}{c|}{$\mathrm{R}=-\left(\mathrm{CH}_{2}\right)_{\mathrm{n}} \mathrm{CH}_{3}$} & \multicolumn{3}{c}{$\mathrm{R}=-\mathrm{CH}_{2}\left(\mathrm{CF}_{2}\right)_{\mathrm{n}} \mathrm{CHF}_{2}$} \\
\hline Position of the substituent & $\mathrm{n}$ & Yield, $\%$ & Position of the substituent & $\mathrm{n}$ & Yield, $\%$ \\
\hline para- & 2 & 26.2 & para- & 64.8 & 27.2 \\
para- & 3 & 26.2 & para- & 7 & 33.0 (US) \\
para- & 5 & $23.2(23.1)^{*}$ & & & \\
para- & 6 & 22.4 & meta- & 25.2 (US) \\
para- & 15 & $11.4(21.3)^{*}$ & & & \\
\hline
\end{tabular}

\footnotetext{
* - synthesis via alkyl halides; US - ultrasonic treatment.
} 


\section{Experimental}

The electronic absorption spectra (EAS) were recorded on a SPEC SSP-715 scanning spectrometer in chloroform, the IR spectra were taken on an Avatar 360 FT-IR in $\mathrm{KBr}$ pellets, the ${ }^{1} \mathrm{H}$ NMR spectra were recorded on a Bruker $500 \mathrm{MHz}$ instrument in deuterated chloroform (TMS as the internal standard) in the joint research center "The Upper-Volga Regional Center of PhysicoChemical Studies" of the G.A. Krestov Institute of Solution Chemistry of the Russian Academy of Sciences. The TLC was performed on Silufol plates. The solvents used were dried and purified by standard procedures. ${ }^{[19]}$

4-Ethoxycarbonylmethyleneoxybenzaldehyde (2, $\mathrm{X}=\mathrm{OCH}_{2}$, $R=E t) .5 .0 \mathrm{~g}(40.9 \mathrm{mmol})$ of 4-oxybenzaldehyde, $9.0 \mathrm{~mL}(85.1$ $\mathrm{mmol})$ of ethyl ester of chloroacetic acid, $3.0 \mathrm{~g}(21.7 \mathrm{mmol})$ of potassium carbonate in DMF $(75 \mathrm{~mL})$ were refluxed with stirring for $1 \mathrm{~h}$. The mixture was then cooled, poured into $200 \mathrm{~mL}$ of water and extracted with ether. The ethereal solution was washed with water and dried with sodium sulfate. Ether was evaporated off and the residue was distilled under the vacuum of a water jet pump, the fraction boiling at $\sim 185{ }^{\circ} \mathrm{C}$ was collected. Yield: $7.3 \mathrm{~g}(86 \%) .{ }^{1} \mathrm{H}$ NMR $\left(\mathrm{CCl}_{4}\right) \delta$ ppm: $9.57 \mathrm{~s}(1 \mathrm{H}, \mathrm{CHO}) ; 7.57 \mathrm{~d}(2 \mathrm{H}, J=8.0 \mathrm{~Hz}, 2.6-$ $\mathrm{H}) ; 6.72 \mathrm{~d}(2 \mathrm{H}, J=8.0 \mathrm{~Hz}, 3.5-\mathrm{H}) ; 4.45 \mathrm{~s}\left(2 \mathrm{H}, \mathrm{OCH}_{2} \mathrm{CO}\right) ; 4.00 \mathrm{q}$ $\left(2 \mathrm{H},{ }^{1} J=7.1 \mathrm{~Hz}, \mathrm{OCH}_{2}-\mathrm{Et}\right) ; 1.15 \mathrm{t}\left(3 \mathrm{H},{ }^{1} J=7.1 \mathrm{~Hz}, \mathrm{CH}_{3}-\mathrm{OEt}\right)$.

4-Methoxycarbonylbenzaldehyde $(2, \quad X=-, \quad R=M e)$. To a stirred suspension of 4-carboxybenzaldehyde (12.0 g, $0.08 \mathrm{~mol})$ and potash $(35.0 \mathrm{~g}, 0.25 \mathrm{~mol})$ in $250 \mathrm{~mL}$ of acetone methyl iodide $(5.5 \mathrm{~mL}, 0.088 \mathrm{~mol})$ was added. The mixture was refluxed with stirring for $4 \mathrm{~h}$, the residue was filtered off, washed with acetone and the acetone was then evaporated. The residue was recrystallized from methanol. Yield: $11.6 \mathrm{~g}(88 \%)$, m.p. $60-62{ }^{\circ} \mathrm{C} .{ }^{1} \mathrm{H}$ NMR $\left(\mathrm{CCl}_{4}\right) \delta$ ppm: $9.53 \mathrm{~s}(1 \mathrm{H}, \mathrm{CHO}) ; 7.72 \mathrm{~d}(2 \mathrm{H}, J=8.1 \mathrm{~Hz}, 3.5-\mathrm{H})$; $7.57 \mathrm{~d}(2 \mathrm{H}, J=8.1 \mathrm{~Hz}, 2.6-\mathrm{H}) ; 4.30 \mathrm{~s}\left(3 \mathrm{H}, \mathrm{OCH}_{3}\right)$.

4-Hexadecyloxybenzaldehyde (7). A mixture of $20.0 \mathrm{~g}$ $(0.164 \mathrm{~mol})$ of 4-oxybenzaldehyde, $50 \mathrm{~mL}(0.164 \mathrm{~mol})$ of cetyl bromide, $25.0 \mathrm{~g}(0.181 \mathrm{~mol})$ of potassium carbonate and $200 \mathrm{~mL}$ of $n$-butanol was refluxed with stirring for $3 \mathrm{~h}$. The mixture was then cooled, the precipitate was filtered, washed with water and air-dried at ambient temperature. Yield: 43.9 g (77 \%), m.p. $41-42{ }^{\circ} \mathrm{C} .{ }^{1} \mathrm{H}$ NMR $\left(\mathrm{CCl}_{4}\right) \delta$ ppm: $9.89 \mathrm{~s}(1 \mathrm{H}, \mathrm{CHO}) ; 7.83 \mathrm{~d}(2 \mathrm{H}, J=8.5 \mathrm{~Hz}, 2.6-$ $\mathrm{H}) ; 7.01 \mathrm{~d}(2 \mathrm{H}, J=8.5 \mathrm{~Hz}, 3.5-\mathrm{H}) ; 4.05 \mathrm{t}\left(2 \mathrm{H},{ }^{1} J=7.0 \mathrm{~Hz}, \mathrm{OCH}_{2}\right)$; $1.83 \mathrm{qv}\left(2 \mathrm{H},{ }^{1} J=7.0 \mathrm{~Hz}, \mathrm{CH}_{2}\right) ; 1.44-1.52 \mathrm{~m}\left(2 \mathrm{H}, \mathrm{CH}_{2}\right) ; 1.23-1.41 \mathrm{~m}$ $\left(24 \mathrm{H}, \mathrm{CH}_{2}\right) ; 0.90$ t $\left(3 \mathrm{H},{ }^{1} \mathrm{~J}=7.0 \mathrm{~Hz}, \mathrm{CH}_{3}\right)$.

5-(4-Methoxycarbonylphenyl)-10,15,20-triphenylporphyrin $(4, X=-; R=M e)$. To a solution of $410 \mathrm{mg}(2.5 \mathrm{mmol})$ of 4-methoxycarbonylbenzaldehyde, $0.7 \mathrm{~mL}(10 \mathrm{mmol})$ of pyrrole and $0.9 \mathrm{~mL}(8.9 \mathrm{mmol})$ of benzaldehyde in $1000 \mathrm{~mL}$ of methylene chloride $1.0 \mathrm{~g}$ of thinly powdered ammonium chloride was added, then in an argon atmosphere a solution of $0.3 \mathrm{~mL}(2.4 \mathrm{mmol})$ of boron trifluoride etherate in $10 \mathrm{~mL}$ of methylene chloride was dropwise added. The mixture was stirred for additional $1 \mathrm{~h}$ and then treated with $1.85 \mathrm{~g}(7.5 \mathrm{mmol})$ of $p$-chloroanil and stirred overnight. The solvent was removed, the residue washed with sodium hydroxide and water to neutral $\mathrm{pH}$ and then air-dried at $70^{\circ} \mathrm{C}$. The mixture of porphyrins was then dissolved in methylene chloride and subjected to chromatography on aluminum oxide (Brockmann II grade), porphyrin was eluted as the second zone, after tetraphenylporphyrin. The eluate was evaporated to dryness, the residue was dissolved in benzene and subjected to chromatography on silica gel (L 100/250), using benzene as an eluent, the solvent was evaporated and the porphyrin was precipitated with methanol. The precipitate was filtered, washed with methanol and air-dried. Yield $136 \mathrm{mg}(8.1 \%)$. $\mathrm{R}_{\mathrm{f}}=0.63$ (benzene-methanol, $10: 1$ ). EAS $\lambda_{\max }(\lg \varepsilon): 645$ (3.72); 589 (3.88); 549 (3.97); 514 (4.35); 417 (5.59). ${ }^{1} \mathrm{Hax} \mathrm{NMR}\left(\mathrm{CDCl}_{3}\right) \delta \mathrm{ppm}$ : $8.86-8.91 \mathrm{~m}(6 \mathrm{H}, \beta-\mathrm{H}) ; 8.82 \mathrm{~d}(2 \mathrm{H}, J=4.5 \mathrm{~Hz}, 3.7-\mathrm{H}) ; 8.46 \mathrm{~d}(2 \mathrm{H}$, $\left.{ }^{1} J=8.2 \mathrm{~Hz}, 2.6-\mathrm{H}-\mathrm{Ar}\right) ; 8.33 \mathrm{~d}\left(2 \mathrm{H},{ }^{1} J=8.2 \mathrm{~Hz}, 3.5-\mathrm{H}-\mathrm{Ar}\right) ; 8.24 \mathrm{~d}$ $\left(6 \mathrm{H},{ }^{2} J=6.9 \mathrm{~Hz}, 2.6-\mathrm{H}-\mathrm{Ph}\right) ; 7.76-7.84 \mathrm{~m}(9 \mathrm{H}, 3.4 .5-\mathrm{H}-\mathrm{Ph}) ; 4.14 \mathrm{~s}$ $\left(3 \mathrm{H}, \mathrm{OCH}_{3}\right) ;-2.77$ bs $(2 \mathrm{H}, \mathrm{NH})$.
5-(4-Ethoxycarbonylmethyleneoxyphenyl)-10,15,20triphenylporphine $\left(4, \mathrm{X}=\mathrm{OCH}_{2}, \mathrm{R}=\mathrm{Et}\right.$ ). To a refluxing solution of $4 \mathrm{~mL}(53.8 \mathrm{mmol}, \sim 2 \%)$ of trifluoroacetic acid in $300 \mathrm{~mL}$ of $p$-xylene under argon was gradually added a solution of $3.8 \mathrm{~g}$ (18.05 mmol) 4-ethoxycarbonylbenzaldehyde, $5.5 \mathrm{~mL}$ (54.18 mmol) benzaldehyde and $5.0 \mathrm{~mL}(72.2 \mathrm{mmol})$ pyrrole in $50 \mathrm{~mL} p$-xylene. The mixture was refluxed for $0.5 \mathrm{~h}$ under argon and then for $1 \mathrm{~h}$ under a stream of air. The solvent was removed by distillation with water vapor, the residue filtered, washed with water and dried The mixture was dissolved in chloroform and subjected to chromatography on a column with $\mathrm{Al}_{2} \mathrm{O}_{3}$ (II Brockmann grade), eluting the first fraction of tetraphenylporphyrin with chloroform. The eluate was evaporated and the porphyrin precipitated with methanol. Yield: $1.1 \mathrm{~g}(9.9 \%)$. The second fraction was eluted with a mixture of chloroform-methanol, evaporated to dryness and subjected to chromatography on silica gel (L 100/250) eluting with methylene chloride and collecting the second porphyrinic fraction. The eluate was evaporated and the porphyrin was precipitated with methanol. Yield: $1.3 \mathrm{~g}(10.0 \%)$. EAS $\lambda_{\max }(\lg \varepsilon): 650$ (3.83); 594 (4.03); 554 (4.03); 518 (4.23); 422 (5.66). ${ }^{1} \mathrm{H}$ NMR $\delta$ ppm: $8.92-8.99 \mathrm{~m}(8 \mathrm{H}, \beta-\mathrm{H}) ; 8.25 \mathrm{~d}(6 \mathrm{H}, J=6.6 \mathrm{~Hz}, 2.6-\mathrm{H}-\mathrm{Ph}) ; 8.00 \mathrm{~d}$ $\left(2 \mathrm{H},{ }^{1} J=7.6 \mathrm{~Hz}, 2.6-\mathrm{H}-\mathrm{Ar}\right) ; 7.74-7.83 \mathrm{~m}(9 \mathrm{H}, 3.4 .5-\mathrm{H}-\mathrm{Ph}) ; 7.19$ d $\left(2 \mathrm{H},{ }^{1} J=7.6 \mathrm{~Hz}, 3.5-\mathrm{H}-\mathrm{Ar}\right) ; 4.84 \mathrm{~s}\left(2 \mathrm{H}, \mathrm{OCH}_{2} \mathrm{CO}\right) ; 4.34 \mathrm{q}(2 \mathrm{H}$, $\left.{ }^{2} J=7.2 \mathrm{~Hz}, \mathrm{OCH}_{2}-\mathrm{Et}\right) ; 1.34 \mathrm{t}\left(3 \mathrm{H},{ }^{2} J=7.2 \mathrm{~Hz}, \mathrm{CH}_{3}-\mathrm{Et}\right) ;-2.74 \mathrm{bs}$ $(2 \mathrm{H}, \mathrm{NH})$.

5-(4-Methoxycarbonylphenyl)-2,3, 7, 8, 12,18-hexamethyl13,17-di-n-amyloporphine (13, $X=-, R=M e)$. To a solution of $1.38 \mathrm{~g}$ (4.39 mmol) of 4,4'-dimethyl-3,3'-diamyldipyrromethane ${ }^{[18]}$ and $1.1 \mathrm{~g}(8.93 \mathrm{mmol})$ of 2-formyl-3,4-dimethylpyrrole ${ }^{[18]}$ in $100 \mathrm{~mL}$ of butanol at ambient temperature and stirring, conc. hydrobromic acid $(2.0 \mathrm{~mL}, \sim 16.6 \mathrm{mmol})$ was added (biladiene was precipitated),

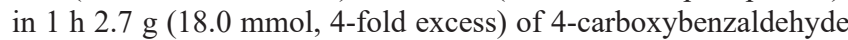
was added, the mixture was refluxed for 4 ч, then $1.1 \mathrm{~g}(4.39 \mathrm{mmol})$ of iodine was added, the mixture was stirred for $15 \mathrm{~min}$ and chilled. Butanol was removed by steam distillation, the residue was filtered, washed with water and air-dried at $70^{\circ} \mathrm{C}$. The mixture was dissolved in methylene chloride and subjected to chromatography on silica gel eluting with methylene chloride. The eluate was evaporated and the porphyrin was precipitated with methanol. Yield: $100 \mathrm{mg}(3.5 \%)$, $13(\mathrm{X}=-; \mathrm{R}=\mathrm{Bu})$. The insoluble precipitate was stirred for several days at ambient temperature in a mixture of sulfuric acid $(4 \mathrm{~mL})$ and methanol $(150 \mathrm{~mL})$. Half of the methanol was removed, the rest was diluted with water and neutralized with aqueous ammonia, the precipitate was filtered, washed with water and air-dried at $70{ }^{\circ} \mathrm{C}$. It was then dissolved in methylene chloride and chromatographed on silica gel eluting with methylene chloride. The eluate was evaporated and the porphyrin was precipitated with methanol. Yield: $0.6 \mathrm{~g}(20.8 \%), 13(\mathrm{X}=-; \mathrm{R}=\mathrm{Bu}): \mathrm{R}_{\mathrm{f}}=0.51$ (benzene). EAS $\lambda_{\text {max }}$ (lge): 623 (3.63); 571 (3.90); 537 (3.94); 504 (4.21); 404 (5.25). ${ }^{1} \mathrm{H}$ NMR $\delta$ ppm: $10.18 \mathrm{~s}(2 \mathrm{H}, 10.20-\mathrm{H}) ; 9.97 \mathrm{~s}(1 \mathrm{H}, 15-\mathrm{H}) ; 8.46 \mathrm{~d}$ $(2 \mathrm{H}, J=7.8 \mathrm{~Hz}, 2.6-\mathrm{H}-\mathrm{Ar}) ; 8.21 \mathrm{~d}(2 \mathrm{H}, J=7.8 \mathrm{~Hz}, 3.5-\mathrm{H}-\mathrm{Ar}) ; 4.53 \mathrm{t}$ $\left(8 \mathrm{H},{ }^{1} J=6.9 \mathrm{~Hz}, \mathrm{OCH}_{2}-\mathrm{Bu}\right) ; 4.04 \mathrm{t}\left(4 \mathrm{H},{ }^{2} J=7.5 \mathrm{~Hz}, \mathrm{CH}_{2}-\mathrm{Am}\right) ; 3.62$ $\mathrm{s}\left(6 \mathrm{H}, 12.18-\mathrm{CH}_{3}\right) ; 3.51 \mathrm{~s}\left(6 \mathrm{H}, 2.8-\mathrm{CH}_{3}\right) ; 2.48 \mathrm{~s}\left(6 \mathrm{H}, 3.7-\mathrm{CH}_{3}\right) ; 2.32$ qv $\left(4 \mathrm{H},{ }^{2} J=7.5 \mathrm{~Hz}, \mathrm{CH}_{2}-\mathrm{Am}\right) ; 1.94 \mathrm{qv}\left(2 \mathrm{H},{ }^{1} J=6.9 \mathrm{~Hz}, \mathrm{CH}_{2}-\mathrm{Bu}\right)$; $1.75 \mathrm{qv}\left(4 \mathrm{H},{ }^{2} \mathrm{~J}=7.5 \mathrm{~Hz}, \mathrm{CH}_{2}-\mathrm{Am}\right) ; 1.52-1.46 \mathrm{~m}\left(6 \mathrm{H}, \mathrm{CH}_{2}-\mathrm{Bu}+\mathrm{CH}_{2}-\right.$ $\mathrm{Am}) ; 1.17 \mathrm{t}\left(3 \mathrm{H},{ }^{1} J=6.9 \mathrm{~Hz}, \mathrm{CH}_{3}-\mathrm{Bu}\right) ; 0.99 \mathrm{t}\left(6 \mathrm{H},{ }^{2} J=7.5 \mathrm{~Hz}, \mathrm{CH}_{3}-\right.$ $\mathrm{Am}) ;-3.36$ bs $(2 \mathrm{H}, \mathrm{NH}) .13(\mathrm{X}=-; \mathrm{R}=\mathrm{Me}): \mathrm{R}_{\mathrm{f}}=0.42$ (benzene). EAS $\lambda_{\text {max }}$ (lge): 624 (3.83); 571 (3.88); 538 (3.91); 504 (4.18); 405 (5.23). ${ }^{1} \mathrm{H}$ NMR $\delta$ ppm: $10.19 \mathrm{~s}(2 \mathrm{H}, 10.20-\mathrm{H}) ; 9.95 \mathrm{~s}(1 \mathrm{H}, 15-\mathrm{H})$; $8.43 \mathrm{~d}(2 \mathrm{H}, J=7.8 \mathrm{~Hz}, 2.6-\mathrm{H}-\mathrm{Ar}) ; 8.21 \mathrm{~d}(2 \mathrm{H}, J=7.8 \mathrm{~Hz}, 3.5-\mathrm{H}-$ $\mathrm{Ar}) ; 4.35 \mathrm{~s}\left(3 \mathrm{H}, \mathrm{OCH}_{3}\right) ; 4.05 \mathrm{t}\left(4 \mathrm{H},{ }^{1} J=7.5 \mathrm{~Hz}, \mathrm{CH}_{2}-\mathrm{Am}\right) ; 3.62 \mathrm{~s}$ $\left(6 \mathrm{H}, 12.18-\mathrm{CH}_{3}\right) ; 3.54 \mathrm{~s}\left(6 \mathrm{H}, 2.8-\mathrm{CH}_{3}\right) ; 2.50 \mathrm{~s}\left(6 \mathrm{H}, 3.7-\mathrm{CH}_{3}\right) ; 2.33$ qv $\left(4 \mathrm{H},{ }^{1} J=7.5 \mathrm{~Hz}, \mathrm{CH}_{2}-\mathrm{Am}\right) ; 1.75 \mathrm{qv}\left(4 \mathrm{H},{ }^{1} J=7.5 \mathrm{~Hz}, \mathrm{CH}_{2}-\mathrm{Am}\right)$; $1.55 \mathrm{~s}\left(4 \mathrm{H},{ }^{1} \mathrm{~J}=7.5 \mathrm{~Hz}, \mathrm{CH}_{2}-\mathrm{Am}\right) ; 0.99 \mathrm{t}\left(6 \mathrm{H},{ }^{1} \mathrm{~J}=7.5 \mathrm{~Hz}, \mathrm{CH}_{3}-\mathrm{Am}\right)$; -3.34 bs $(2 \mathrm{H}, \mathrm{NH})$.

5-(4-Butoxycarbonylmethyleneoxyphenyl)-2,3, 7,8,12,18hexamethyl-13,17-di-n-amylporphine (13, X=OCH $; \quad R=B u)$. To a solution of $0.67 \mathrm{~g}$ (2.13 mmol) 4,4'-dimethyl-3,3'- 
diamyldipyrromethane and $0.52 \mathrm{~g}(4.26 \mathrm{mmol})$ of 2-formyl-3,4dimethylpyrrole in $50 \mathrm{~mL}$ of $n$-butanol at ambient temperature, concentrated hydrobromic acid $(1.0 \mathrm{~mL}, 8.3 \mathrm{mmol})$ was added with stirring. The mixture was stirred for $1 \mathrm{~h}$, then $3.0 \mathrm{~mL}$ ( $\sim 6$-fold excess) of 4-ethoxycarbonylmethyleneoxybenzaldehyde was added refluxed for $4 \mathrm{~h}$. After cooling, $2 \mathrm{~mL}$ of conc. aqueous ammonia was introduced. The precipitate was filtered off, washed with methanol and air-dried. Then it was dissolved in chloroform and purified by column chromatography on silica gel (L 100/250), using chloroform-methanol mixture $(100: 1)$ as the eluent. Yield: $0.72 \mathrm{~g}$ $(45.6 \%) . \mathrm{R}_{\mathrm{f}}=0.86$ (benzene:methanol=20:1). EAS $\lambda_{\text {max }}(\lg \varepsilon): 623.5$ (3.62); 571 (3.95); 537 (3.97); 503 (4.27); 404.2 (5.36). IR (KBr) $\mathrm{cm}^{-1}: v_{\mathrm{CO}}-1633$. ' $\mathrm{H}$ NMR $\delta \mathrm{ppm}: 10.16 \mathrm{~s}(2 \mathrm{H}, 10.20-\mathrm{H}) ; 9.96 \mathrm{~s}(1 \mathrm{H}$, $15-\mathrm{H}) ; 7.93 \mathrm{~d}(2 \mathrm{H}, J=8.0 \mathrm{~Hz}, 2.6-\mathrm{H}-\mathrm{Ar}) ; 7.27 \mathrm{~d}(2 \mathrm{H}, J=8.0 \mathrm{~Hz}, 3.5-$ $\mathrm{H}-\mathrm{Ar}) ; 4.95 \mathrm{~s}\left(2 \mathrm{H}, \mathrm{OCH}_{2} \mathrm{CO}\right) ; 4.39 \mathrm{t}\left(2 \mathrm{H},{ }^{1} J=7.7 \mathrm{~Hz}, \mathrm{OCH}_{2}-\mathrm{Bu}\right)$; $4.05 \mathrm{t}\left(4 \mathrm{H},{ }^{2} \mathrm{~J}=7.5 \mathrm{~Hz}, \mathrm{CH}_{2}-\mathrm{Am}\right) ; 3.65 \mathrm{~s}\left(6 \mathrm{H}, 12.18-\mathrm{CH}_{3}\right) ; 3.55 \mathrm{~s}$ $\left(6 \mathrm{H}, 2.8-\mathrm{CH}_{3}\right) ; 2.50 \mathrm{~s}\left(6 \mathrm{H}, 3.7-\mathrm{CH}_{3}\right) ; 2.33 \mathrm{qv}\left(4 \mathrm{H},{ }^{2} \mathrm{~J}=7.5 \mathrm{~Hz}, \mathrm{CH}_{2}-\right.$ $\mathrm{Am}) ; 1.71-1.78 \mathrm{~m}\left(6 \mathrm{H}, \mathrm{CH}_{2}-\mathrm{Bu}, \mathrm{Am}\right) ; 1.52-1.60 \mathrm{~m}\left(6 \mathrm{H}, \mathrm{CH}_{2}-\mathrm{Bu}\right.$, $\mathrm{Am}) ; 1.06 \mathrm{t}\left(3 \mathrm{H},{ }^{1} \mathrm{~J}=7.7 \mathrm{~Hz}, \mathrm{CH}_{3}-\mathrm{Bu}\right) ; 0.99 \mathrm{t}\left(6 \mathrm{H},{ }^{2} \mathrm{~J}=7.5 \mathrm{~Hz}, \mathrm{CH}_{3}-\right.$ $\mathrm{Am}) ;-3.16$ bs $(1 \mathrm{H}, \mathrm{NH}) ;-3.33$ bs $(1 \mathrm{H}, \mathrm{NH})$.

5-(4-Carboxyphenyl)-10,15,20-triphenylporphine (5, $X=-)$. $100 \mathrm{mg}(0.15 \mathrm{mmol})$ of 5-(4-methoxycarbonyl)phenyl-10,15,20triphenylporphine, and $100 \mathrm{mg}(1.8 \mathrm{mmol})$ of potassium hydroxide was dissolved in a mixture of propyl alcohol $(20 \mathrm{~mL})$, THF $(20 \mathrm{~mL})$ and water $(2.5 \mathrm{~mL})$ and refluxed for $3 \mathrm{~h}$. The solution was then cooled and treated with dilute hydrochloric acid until the color changed from crimson to green. The formed precipitate was filtered, washed with water, dissolved in a mixture of chloroform-methanol and washed with water in a separatory funnel until the color changed from green to red. The solution was dried with sodium sulfate, chloroform was evaporated and the residue was air-dried. Yield: $80 \mathrm{mg}(81.8 \%)$. EAS $\lambda_{\text {max }}$ (lge): 646 (3.67); 590 (3.81); 551 (3.94); 516 (4.25); 419 (5.63).

Similarly obtained were:

5-(4-Carboxymethyleneoxyphenyl)-10,15,20-triphenylporphine (5, $\mathrm{X}=\mathrm{OCH}_{2}$ ). Yield: $97.5 \%$. EAS $\lambda_{\text {max }}$ (lge): 649 (3.81); 594 (4.00); 553 (4.05); 518 (4.19); 420 (5.63).

5-(4-Carboxyphenyl)-2,3,7,8,12,18-hexamethyl-13,17-di-namylporphine (14, $X=-$ ). Yield: $89.5 \%$. EAS $\lambda_{\max } \mathrm{nm}(\lg \varepsilon)$ : 646 (3.65); 590 (3.78); 550 (3.91); 515 (4.25); 419 (5.62).

5-(4-Carboxyphenyl)-10,15,20-tris(4-hexadecyloxyphenyl) porphine (9). To a refluxing solution of $2 \mathrm{~mL}(26.9 \mathrm{mmol})$ of trifluoroacetic acid in $300 \mathrm{~mL}$ of $p$-xylene in an argon atmosphere it was gradually added a solution of $3.0 \mathrm{~g}(18.27 \mathrm{mmol})$ of 4-methoxycarbonylbenzaldehyde 6,18.9 g $(54.5 \mathrm{mmol})$ of 4-hexadecyloxybenzaldehyde 7 and $5.0 \mathrm{~mL}(72.2 \mathrm{mmol})$ of pyrrole in $p$-xylene $(50 \mathrm{~mL})$. The mixture was refluxed for $0.5 \mathrm{~h}$ in the inert atmosphere and then for $1 \mathrm{~h}$ under a stream of air. The solvent was then steam distilled, the residue filtered and dried at $70{ }^{\circ} \mathrm{C}$. The porphyrin mixture was dissolved in methylene chloride and chromatographed on silica gel (L 100/250), using methylene chloride as the eluent. A secondary purification run was performed on $\mathrm{Al}_{2} \mathrm{O}_{3}$ (II Brockmann grade), using benzene as the eluent. The second porphyrin band was collected, the eluent evaporated and the porphyrin was precipitated with methanol, filtered and air-dried. The obtained 5-(4-methoxycarbonyl)-10,15,20-tris(4-hexadecyloxyphenyl)porphine 8 was refluxed for $4 \mathrm{~h}$ in a solution of $\mathrm{KOH}(5.0 \mathrm{~g}, 89.1 \mathrm{mmol})$ in $10 \mathrm{~mL}$ of water and $150 \mathrm{~mL}$ of propyl alcohol. The reaction mixture was then treated with water, the formed precipitate was filtered, washed with water and dried. Yield of the potassium salt: $3.2 \mathrm{~g}$. The salt was dissolved in methylene chloride and shaken with $5 \%$ hydrochloric acid. The organic layer was then washed with water until the color changed from green to red. The solution was evaporated and the porphyrin was precipitated with methanol, filtered and air-dried at ambient temperature. Yield: $2.4 \mathrm{~g}(9.6 \%)$. EAS $\lambda_{\text {ma }}$ (lge): 649 (3.83); 593 (3.82); 555 (4.00); 518 (4.16); 421 (5.43). ${ }^{1} \mathrm{H}$ NMR $\delta$ ppm: 8.88-8.97 m (6H, $\beta$-H); 8.78-8.84 m $(2 \mathrm{H}, \beta-\mathrm{H})$; 8.46$8.54 \mathrm{~m}(2 \mathrm{H}, 2.6-\mathrm{H}-\mathrm{Ar}) ; 8.31-8.39 \mathrm{~m}(2 \mathrm{H}, 3.5-\mathrm{H}-\mathrm{Ar}) ; 8.09-8.17 \mathrm{~m}$
(6H, 2.6-H-Ar'); 7.26-7.34 m (6H, 3.5-H-Ar'); 4.22-4.32 m (6H, $\left.\mathrm{OCH}_{2}\right) ; 1.96-2.07 \mathrm{~m}\left(6 \mathrm{H}, \mathrm{CH}_{2}\right) ; 1.61-1.70 \mathrm{~m}\left(6 \mathrm{H}, \mathrm{CH}_{2}\right) ; 1.56-1.12$ $\mathrm{m}\left(72 \mathrm{H}, \mathrm{CH}_{2}\right) ; 0.85-0.96 \mathrm{~m}\left(9 \mathrm{H}, \mathrm{CH}_{3}\right) ;-2.72$ bs $(2 \mathrm{H}, \mathrm{NH})$.

5,10,15,20-Tetrakis(4-carboxyphenyl)porphine (11, para). The solution of $0.7 \mathrm{~mL}(10.1 \mathrm{mmol})$ of pyrrole $1,1.5 \mathrm{~g}(10 \mathrm{mmol})$ of 4-carboxybenzaldehyde $\mathbf{1 0}$ (para) and $1.7 \mathrm{~mL}(18.0 \mathrm{mmol})$ of acetic anhydride in a mixture of nitrobenzene $(15 \mathrm{~mL})$ and propionic acid $(35 \mathrm{~mL})$ was heated and refluxed for $2 \mathrm{~h}$. The reaction mixture was then maintained at room temperature overnight. The porphyrin precipitate was filtered, washed with methanol and air-dried at $70{ }^{\circ} \mathrm{C}$. Yield: $1.1 \mathrm{~g}(55.6 \%)$. EAS $(2 \% \mathrm{KOH}$ in water $) \lambda_{\max }(\lg \varepsilon)$ : 651 (3.88); 600 flat (3.92); 565 (4.04); 524 (4.10); 413 (5.15).

Similarly obtained was:

5,10,15,20-Tetrakis(3-carboxyphenyl)porphine (11, meta). Yield: $43.0 \%$. EAS (2\% KOH in water) $\lambda_{\max }(\lg \varepsilon): 639$ (3.66); 581 (3.78); 554 (3.85); 518 (4.09); 414 (5.49).

5-(4-Carboxymethyleneoxyphenyl)-2, 3, 7, 8, 12,18hexamethyl-13,17-diamylporphine $\left(14, \mathrm{X}=\mathrm{OCH}_{2}\right)$. A solution of $0.44 \mathrm{~g}(0.59 \mathrm{mmol})$ of 5-(4-butoxycarbonylmethyleneoxyphenyl)2,3,7,8,12,18-hexamethyl-13,17-di- $n$-amylporphine $\mathbf{1 3}\left(\mathrm{X}=\mathrm{OCH}_{2}\right.$; $\mathrm{R}=\mathrm{Bu})$ in $50 \mathrm{~mL}$ of methanol in the presence of $\mathrm{KOH}(1.0 \mathrm{~g})$ in $10 \mathrm{~mL}$ of water was refluxed for $24 \mathrm{~h}$. The formed precipitate was filtered, washed with methanol and dried. $290 \mathrm{mg}(0.37 \mathrm{mmol})$ of the obtained potassium salt of 5-(4-carboxymethyleneoxyphenyl)$2,3,7,8,12,18$-hexamethyl-13,17-di- $n$-amylporphine was treated with a solution of $1 \mathrm{~mL}$ of $35 \%$ hydrochloric acid in $5 \mathrm{~mL}$ of methanol, then water $(20 \mathrm{~mL})$ was introduced. The formed precipitate of the carbonic acid was filtered, washed with water and air-dried at $70{ }^{\circ} \mathrm{C}$. Yield: $250 \mathrm{mg}(\sim 100 \%)$. EAS $\lambda_{\max }$ (lge): 621 (3.52); 569.5 (3.87); 537 (3.88); 503 (4.18); 402.6 (5.29).

5-[4-(1,1,9-H-Perfluorononyloxycarbonyl) phenyl]2,3,7,8,12,18-hexamethyl-13,17-di-n-amylporphine (16). A mixture of $50 \mathrm{mg}(0.073 \mathrm{mmol})$ of 5-(4-carboxyphenyl)-2,3,7,8,12,18hexamethyl-13,17-diamylporphine $\mathbf{1 4}(\mathrm{X}=-), 50 \mathrm{mg}(0.116 \mathrm{mmol})$ of $n$-perfluoro-1,1,9- $H$-nonyl alcohol, $6 \mathrm{mg}(0.049 \mathrm{mmol})$ of DMAP and $30 \mathrm{mg}(0.156 \mathrm{mmol})$ of EDAC was dissolved in $15 \mathrm{~mL}$ methylene chloride and stirred at $0{ }^{\circ} \mathrm{C}$ for $1.5 \mathrm{~h}$, then at ambient temperature until the reaction was complete according to TLC (5 days). The reaction mixture was purified by chromatography on silica gel (L 100/250), using methylene chloride as the eluent. The eluate was evaporated and the porphyrin was precipitated with methanol. The residue was filtered, washed with methanol and dired. Yield: $53.8 \mathrm{mg}(66.1 \%) . \mathrm{R}_{\mathrm{f}}=0.67$ (benzene). EAS $\lambda_{\max } \mathrm{nm}$ (lge): 624 (3.71); 581 (3.86); 538 (3.99); 504 (4.25); 405 (5.32). IR $\mathrm{cm}^{-1}: v_{\mathrm{OCO}}-1737 ; \mathrm{v}_{\mathrm{CF}}-1213 .{ }^{1} \mathrm{H}$ NMR $\delta \mathrm{ppm}: 10.18 \mathrm{~s}(2 \mathrm{H}, 10.20-$ $\mathrm{H}) ; 9.97 \mathrm{~s}(1 \mathrm{H}, 15-\mathrm{H}) ; 8.46 \mathrm{~d}(2 \mathrm{H}, J=7.8 \mathrm{~Hz}, 2.6-\mathrm{H}-\mathrm{Ar}) ; 8.21 \mathrm{~d}(2 \mathrm{H}$, $J=7.8 \mathrm{~Hz}, 3.5-\mathrm{H}-\mathrm{Ar}) ; 6.10 \mathrm{tt}\left(1 \mathrm{H},{ }^{1} J=5.1 \mathrm{~Hz},{ }^{2} J=51.9 \mathrm{~Hz}, \mathrm{CHF}_{2}\right)$; $5.07 \mathrm{t}\left(2 \mathrm{H},{ }^{3} \mathrm{~J}=13.4 \mathrm{~Hz}, \mathrm{OCH}_{2}\right) ; 4.04 \mathrm{t}\left(4 \mathrm{H},{ }^{4} \mathrm{~J}=7.6 \mathrm{~Hz}, \mathrm{CH}_{2}-\mathrm{Am}\right)$; $3.64 \mathrm{~s}\left(6 \mathrm{H}, 12.18-\mathrm{CH}_{3}\right) ; 3.54 \mathrm{~s}\left(6 \mathrm{H}, 2.8-\mathrm{CH}_{3}\right) ; 2.43 \mathrm{~s}\left(6 \mathrm{H}, 3.7-\mathrm{CH}_{3}\right)$; $2.33 \mathrm{qv}\left(4 \mathrm{H},{ }^{4} \mathrm{~J}=7.6 \mathrm{~Hz}, \mathrm{CH}_{2}-\mathrm{Am}\right) ; 1.76 \mathrm{qv}\left(4 \mathrm{H},{ }^{4} \mathrm{~J}=7.6 \mathrm{~Hz}, \mathrm{CH}_{2}-\right.$ $\mathrm{Am}) ; 1.57 \mathrm{sc}\left(4 \mathrm{H},{ }^{4} J=7.6 \mathrm{~Hz}, \mathrm{CH}_{2}-\mathrm{Am}\right) ; 1.00 \mathrm{t}\left(6 \mathrm{H},{ }^{4} J=7.6 \mathrm{~Hz}\right.$, $\left.\mathrm{CH}_{3}-\mathrm{Am}\right) ;-2.96$ bs $(2 \mathrm{H}, \mathrm{NH})$.

5-[4-(1,1,9-H-Perfluorononyloxycarbonyl)phenyl]10,15,20-triphenylporphine $(17, R=P h)$. A mixture of $50 \mathrm{mg}$ (0.073 mmol) of 5-(4-carboxyphenyl)-10,15,20-triphenylporphine $5(\mathrm{X}=-), 49 \mathrm{mg}(0.113 \mathrm{mmol})$ of $n$-perfluoro-1,1,9- $H$-nonyl alcohol, $6 \mathrm{mg}(0.049 \mathrm{mmol})$ of DMAP and $30 \mathrm{mg}(0.156 \mathrm{mmol})$ of EDAC was dissolved in $15 \mathrm{~mL}$ of methylene chloride and stirred at $0{ }^{\circ} \mathrm{C}$ for $1.5 \mathrm{~h}$, then at ambient temperature until the reaction was complete according to TLC (1 day). The reaction mixture was purified by chromatography on silica gel (L 100/250), using methylene chloride as the eluent. The eluate was evaporated and the porphyrin was precipitated with methanol. The residue was filtered, washed with methanol and dried. Yield: $51.1 \mathrm{mg}$ $(62.9 \%) . \mathrm{R}_{\mathrm{f}}=0.75$ (benzene). EAS $\lambda_{\max } \mathrm{nm}(\lg \varepsilon): 646$ (3.76); 590 (3.89); 553 (4.00); 516 (4.32); 419 (5.68). IR cm c $^{-1}: v_{\text {OCO }}-1733 ; v_{\mathrm{CF}}$ - 1210. ${ }^{1} \mathrm{H}$ NMR $\delta$ ppm: $8.90 \mathrm{~d}(2 \mathrm{H}, J=4.6 \mathrm{~Hz}, 2.8-\mathrm{H}) ; 8.89 \mathrm{~s}$ $(4 \mathrm{H}, 12.13 .17 .18-\mathrm{H}) ; 8.82 \mathrm{~d}(2 \mathrm{H}, J=4.6 \mathrm{~Hz}, 3.7-\mathrm{H}) ; 8.49 \mathrm{~d}(2 \mathrm{H}$, 
$\left.{ }^{1} J=8.0 \mathrm{~Hz}, 2.6-\mathrm{H}-\mathrm{Ar}\right) ; 8.39 \mathrm{~d}\left(2 \mathrm{H},{ }^{1} J=8.0 \mathrm{~Hz}, 3.5-\mathrm{H}-\mathrm{Ar}\right) ; 8.24$ d $\left(6 \mathrm{H},{ }^{2} J=7.0 \mathrm{~Hz}, 2.6-\mathrm{H}-\mathrm{Ph}\right) ; 7.75-7.85 \mathrm{~m}(9 \mathrm{H}, 3.4 .5-\mathrm{H}-\mathrm{Ph}) ; 6.10$ tt $\left(1 \mathrm{H},{ }^{3} \mathrm{~J}=5.1 \mathrm{~Hz},{ }^{4} \mathrm{~J}=51.9 \mathrm{~Hz}, \mathrm{CHF}_{2}\right) ; 5.05 \mathrm{t}\left(2 \mathrm{H},{ }^{5} \mathrm{~J}=13.3 \mathrm{~Hz}\right.$, $\left.\mathrm{OCH}_{2}\right) ;-2.75$ bs $(2 \mathrm{H}, \mathrm{NH})$.

5 -[4-(1,1,9-H-Perfluorononyloxy)carbonylphenyl]10,15,20-tris(4-n-hexadecyloxy-phenyl)porphine

$(17$, $\left.R=4-\mathrm{C}_{6} \mathrm{H}_{4} \mathrm{OC}_{16} \mathrm{H}_{33}\right)$. A mixture of $52 \mathrm{mg}(0.038 \mathrm{mmol})$ of 5-(4-carboxyphenyl)-10,15,20-tris(4-hexadecyloxyphenyl)porphine $9,33.5 \mathrm{mg}(0.078 \mathrm{mmol})$ of $n$-perfluoro-1,1,9- $H$-nonyl alcohol, $6.5 \mathrm{mg}(0.053 \mathrm{mmol})$ of DMAP and $15 \mathrm{mg}(0.070 \mathrm{mmol})$ of EDAC was dissolved in $15 \mathrm{~mL}$ of anhydrous methylene chloride and stirred at $0{ }^{\circ} \mathrm{C}$ for $1.5 \mathrm{~h}$, then at ambient temperature until the completion of the reaction ( 4 days, TLC). The reaction mixture was purified by chromatography on silica gel (L 100/250), using methylene chloride as the eluent. The eluate was evaporated and the porphyrin was precipitated with methanol. The residue was filtered, washed with methanol and dired. Yield: $30.5 \mathrm{mg}$ (44.7\%). $\mathrm{R}_{\mathrm{f}}=0.83$ (benzene). EAS $\lambda_{\max } \mathrm{nm}(\lg \varepsilon): 651$ (3.53); 593 (3.85); 556 (3.92); 519 (4.16); 423 (5.58). IR cm ${ }^{-1}: v_{\mathrm{OCO}}-1738 ; v_{\mathrm{CF}}$ - 1211. ${ }^{1} \mathrm{H}$ NMR $\delta$ ppm: $8.94 \mathrm{~d}(2 \mathrm{H}, J=4.2 \mathrm{~Hz}, 2.8-\mathrm{H}) ; 8.92 \mathrm{~s}$ $(4 \mathrm{H}, 12.13 .17 .18-\mathrm{H}) ; 8.80 \mathrm{~d}(2 \mathrm{H}, J=4.2 \mathrm{~Hz}, 3.7-\mathrm{H}) ; 8.50 \mathrm{~d}(2 \mathrm{H}$, $\left.{ }^{1} J=8.1 \mathrm{~Hz}, 2.6-\mathrm{H}-\mathrm{Ar}\right) ; 8.40 \mathrm{~d}\left(2 \mathrm{H},{ }^{1} J=8.1 \mathrm{~Hz}, 3.5-\mathrm{H}-\mathrm{Ar}\right) ; 8.15 \mathrm{~d}$ $\left(6 \mathrm{H},{ }^{2} J=8.5 \mathrm{~Hz}, 2.6-\mathrm{H}-\mathrm{Ar}{ }^{\prime}\right) ; 7.32 \mathrm{~d}\left(6 \mathrm{H},{ }^{2} J=8.5 \mathrm{~Hz}, 3.5-\mathrm{H}-\mathrm{Ar}{ }^{\prime}\right)$; $6.12 \mathrm{tt}\left(1 \mathrm{H},{ }^{3} J=51.9 \mathrm{~Hz},{ }^{4} J=5.0 \mathrm{~Hz}, \mathrm{CHF}_{2}\right) ; 5.06 \mathrm{t}\left(2 \mathrm{H},{ }^{5} J=13.3 \mathrm{~Hz}\right.$, $\left.\mathrm{OCH}_{2}\right) ; 4.28 \mathrm{t}\left(6 \mathrm{H},{ }^{6} \mathrm{~J}=7.0 \mathrm{~Hz}, \mathrm{OCH}_{2}\right) ; 2.02 \mathrm{qv}\left(6 \mathrm{H},{ }^{6} \mathrm{~J}=7.0 \mathrm{~Hz}\right.$, $\left.\mathrm{CH}_{2}\right) ; 1.66 \mathrm{qv}\left(12 \mathrm{H},{ }^{6} \mathrm{~J}=7.0 \mathrm{~Hz}, \mathrm{CH}_{2}\right) ; 1.52$ qv $\left(6 \mathrm{H},{ }^{6} J=7.0 \mathrm{~Hz}\right.$, $\left.\mathrm{CH}_{2}\right) ; 1.45$ qv $\left(6 \mathrm{H},{ }^{6} \mathrm{~J}=7.0 \mathrm{~Hz}, \mathrm{CH}_{2}\right) ; 1.26-1.41 \mathrm{~m}\left(54 \mathrm{H}, \mathrm{CH}_{2}\right) ; 0.92$ $\mathrm{t}\left(9 \mathrm{H},{ }^{6} \mathrm{~J}=7.0 \mathrm{~Hz}, \mathrm{CH}_{3}\right) ;-2.71$ bs $(2 \mathrm{H}, \mathrm{NH})$.

5-(4-O-Cholesterylcarboxymethyleneoxyphenyl)2,3,7,8,12,18-hexamethyl-13,17-di-n-amylporphine (18). A solution of $50.0 \mathrm{mg}$ of $(0.073 \mathrm{mmol})$ 5-(4-carboxymethyleneoxyphenyl)2,3,7,8,12,18-hexamethyl-13,17-diamylporphine $\mathbf{1 4}\left(\mathrm{X}=\mathrm{OCH}_{2}\right)$, $45 \mathrm{mg}(0.368 \mathrm{mmol})$ of DMAP and $45 \mathrm{mg}(0.218 \mathrm{mmol})$ of DCC in $15 \mathrm{~mL} \mathrm{THF}$ was stirred at $0{ }^{\circ} \mathrm{C}$ for $1 \mathrm{~h}$, then $275 \mathrm{mg}(0.711 \mathrm{mmol})$ of cholesterol was added and the stirring was maintained for another 30 minutes. The mixture was maintained at ambient temperature for a day. The porphyrin was purified on $\mathrm{Al}_{2} \mathrm{O}_{3}$ (II Brockmann grade), eluting with methylene chloride. The eluate was evaporated and the porphyrin was precipitated with methanol. The precipitate was filtered, washed with methanol and dried. Yield: $9.1 \mathrm{mg}(11.8 \%) . \mathrm{R}_{\mathrm{f}}=0.82$ (benzene:methanol, 20:1). EAS $\lambda_{\text {max }}$ (lge): 624 (3.63); 571 (3.95); 537 (3.97); 503 (4.27); 404 (5.36). IR, $\mathrm{cm}^{-1}: 1660 ; 1710 .{ }^{1} \mathrm{H} \mathrm{NMR}\left(\mathrm{CDCl}_{3}\right) \delta \mathrm{ppm}: 10.17 \mathrm{~s}(2 \mathrm{H}, 10.20-$ $\mathrm{H}) ; 9.97 \mathrm{~s}(1 \mathrm{H}, 15-\mathrm{H}) ; 7.94 \mathrm{~d}(2 \mathrm{H}, J=7.8 \mathrm{~Hz}, 2.6-\mathrm{H}-\mathrm{Ar}) ; 7.28 \mathrm{~d}(2 \mathrm{H}$, $J=7.8 \mathrm{~Hz}, 3.5-\mathrm{H}-\mathrm{Ar}) ; 5.03 \mathrm{~s}\left(2 \mathrm{H}, \mathrm{OCH}_{2}\right) ; 4.06 \mathrm{t}\left(4 \mathrm{H},{ }^{1} J=7.6 \mathrm{~Hz}\right.$, $\left.\mathrm{CH}_{2}-\mathrm{Am}\right) ; 3.65 \mathrm{~s}\left(6 \mathrm{H}, 12.18-\mathrm{CH}_{3}\right) ; 3.55 \mathrm{~s}\left(6 \mathrm{H}, 2.8-\mathrm{CH}_{3}\right) ; 2.50 \mathrm{~s}$ $\left(6 \mathrm{H}, 3.7-\mathrm{CH}_{3}\right) ; 2.32$ qv $\left(4 \mathrm{H},{ }^{1} J=7.6 \mathrm{~Hz}, \mathrm{CH}_{2}-\mathrm{Am}\right) ; 1.75$ qv $(4 \mathrm{H}$, $\left.{ }^{1} J=7.6 \mathrm{~Hz}, \mathrm{CH}_{2}-\mathrm{Am}\right) ; 1.58 \mathrm{sc}\left(4 \mathrm{H},{ }^{1} J=7.6 \mathrm{~Hz}, \mathrm{CH}_{2}-\mathrm{Am}\right) ; 0.98 \mathrm{t}(6 \mathrm{H}$, $\left.{ }^{1} J=7.6 \mathrm{~Hz}, \mathrm{CH}_{2}-\mathrm{Am}\right) ;-3.23$ bs $(2 \mathrm{H}, \mathrm{NH}) ; 1.20-2.15$ (a number of cholesterol residue signals)

5-[4-(10-Methoxycarbonyldecamethyleneoxy)phenyl]10,15,20-tris(4-hexadecyloxyphenyl)porphine (21). A mixture of $500 \mathrm{mg} \quad(0.37 \mathrm{mmol}) \quad$ 5-(4-oxyphenyl)-10,15,20-tris(4hexadecyloxyphenyl)porphine $20,{ }^{[1]} 0.5 \mathrm{~g}(1.79 \mathrm{mmol})$ of methyl ester of 11-bromoundecanoic acid and $2.0 \mathrm{~g}(14.46 \mathrm{mmol})$ of potassium carbonate in $50 \mathrm{~mL}$ of DMF was refluxed for $5 \mathrm{~h}$, then cooled, poured into $200 \mathrm{~mL}$ of water, the precipitate was filtered, washed with water and dried at ambient temperature in air. The obtained porphyrin was dissolved in chloroform and purified on II Brockmann grade aluminum oxide, eluting with chloroform. The eluate was evaporated and the porphyrin was precipitated with methanol. The precipitate was filtered, washed with methanol and dried. Yield: $0.48 \mathrm{~g}(83.7 \%) . \mathrm{R}_{\mathrm{f}}=0.54$ (benzene). EAS $\lambda$ (lge): 650 (3.98); 593 (3.98); 556 (4.19); 519 (4.31); 422 (5.69). IR $\mathrm{cm}^{-1}: v_{\text {OCO }}-1740 .{ }^{1} \mathrm{H}$ NMR $\delta$ ppm: $8.90 \mathrm{~s}(8 \mathrm{H}, \beta$-H $) ; 8.13 \mathrm{~d}$ $(8 \mathrm{H}, J=8.0 \mathrm{~Hz}, 2.6-\mathrm{H}-\mathrm{Ar}) ; 7.30 \mathrm{~d}(8 \mathrm{H}, J=8.0 \mathrm{~Hz}, 3.5-\mathrm{H}-\mathrm{Ar}) ; 4.27 \mathrm{t}$ $\left(8 \mathrm{H},{ }^{1} J=6.4 \mathrm{~Hz}, \mathrm{OCH}_{2}\right) ; 3.71 \mathrm{~s}\left(3 \mathrm{H}, \mathrm{OCH}_{3}\right) ; 2.37 \mathrm{t}\left(2 \mathrm{H},{ }^{2} J=8.0 \mathrm{~Hz}\right.$, $\left.\mathrm{COCH}_{2}\right) ; 1.97-2.07 \mathrm{~m}\left(8 \mathrm{H}, \mathrm{CH}_{2}\right) ; 1.61-1.73 \mathrm{~m}\left(10 \mathrm{H}, \mathrm{CH}_{2}\right)$; $1.55-$
$1.47 \mathrm{~m}\left(8 \mathrm{H}, \mathrm{CH}_{2}\right) ; 1.25-1.47 \mathrm{~m}\left(82 \mathrm{H}, \mathrm{CH}_{2}\right) ; 0.92 \mathrm{t}\left(9 \mathrm{H},{ }^{1} J=6.4 \mathrm{~Hz}\right.$, $\left.\mathrm{CH}_{3}\right) ;-2.71$ bs $(2 \mathrm{H}, \mathrm{NH})$.

5-[4-(10-Carboxymethyleneoxyphenyl]-10,15,20-tris(4hexadecyloxyphenyl)-porphine (22). A mixture of $500 \mathrm{mg}$ $(0.323 \mathrm{mmol})$ of 5-[4-(10-methoxycarbonyldecamethyleneoxy phenyl]-10,15,20-tris(4-hexadecyloxyphenyl)porphine $\mathbf{2 1}$ and a solution of $0.1 \mathrm{~g}(1.78 \mathrm{mmol})$ of $\mathrm{KOH}$ in $1 \mathrm{~mL}$ of water and $30 \mathrm{~mL}$ of $n$-propanol was refluxed for $1 \mathrm{~h}$. The mixture was cooled, the precipitate was filtered, washed with propanol and stirred in a mixture of methylene chloride with water and hydrochloric acid until the complete dissolution. The organic layer was washed with water until the color changed from green to red, methylene chloride was evaporated to a minimal volume and the porphyrin was precipitated with methanol. The precipitate was filtered, washed with methanol and dried. Yield: $330 \mathrm{mg}(66.5 \%) . \mathrm{R}_{\mathrm{f}}=0.91$ (benzene:methanol, 10:1), 0.7 (benzene:methanol, 20:1). EAS $\lambda_{\text {n }}$ (lge): 651 (3.99); 594 (3.97); 557 (4.20); 519 (4.32); 422 (5.72). IR $\mathrm{cm}^{-1}: v_{\mathrm{OCO}}-1705 .{ }^{1} \mathrm{H}$ NMR $\delta$ ppm: $8.87 \mathrm{~s}(8 \mathrm{H}, \beta-\mathrm{H}) ; 8.06-8.15$ $\mathrm{m}(8 \mathrm{H}, 2.6-\mathrm{H}-\mathrm{Ar}) ; 7.21-7.28 \mathrm{~m}(8 \mathrm{H}, 3.5-\mathrm{H}-\mathrm{Ar}) ; 4.15-4.27 \mathrm{~m}(8 \mathrm{H}$, $\left.\mathrm{OCH}_{2}\right) ; 2.35-2.44 \mathrm{~m}\left(2 \mathrm{H}, \mathrm{COCH}_{2}\right) ; 1.92-2.04 \mathrm{~m}\left(8 \mathrm{H}, \mathrm{CH}_{2}\right) ; 1.67-$ $1.74 \mathrm{~m}\left(2 \mathrm{H}, \mathrm{CH}_{2}\right) ; 1.57-1.67 \mathrm{~m}\left(8 \mathrm{H}, \mathrm{CH}_{2}\right) ; 1.22-1.54 \mathrm{~m}\left(82 \mathrm{H}, \mathrm{CH}_{2}\right)$; $0.86-0.96 \mathrm{~m}\left(9 \mathrm{H}, \mathrm{CH}_{3}\right) ;-2.72$ bs $(2 \mathrm{H}, \mathrm{NH})$

5-[4-(10-O-Cholesterylcarboxymethyleneoxy)phenyl]10,15,20-tris(4-hexadecyloxyphenyl)porphine (19). Method A (via chloroanhydride). To a solution of 5-[4-(10-carboxymethyleneoxy)phenyl]-10,15,20-tris(4-hexadecyloxyphenyl)porphine $22(50 \mathrm{mg}, 0.033 \mathrm{mmol})$ in $10 \mathrm{~mL}$ of benzene thionyl chloride $(0.3 \mathrm{~mL}, 3.7 \mathrm{mmol})$ was added and the mixture was refluxed with the protection by a calcium chloride tube for $1 \mathrm{~h}$. The benzene was distilled off, another $10 \mathrm{~mL}$ of benzene were added and again evaporated. To the residue, cholesterol $(300 \mathrm{mg}, 0.776 \mathrm{mmol})$ was added and the mixture was dissolved in $7 \mathrm{~mL}$ of pyridine. The solution was stirred at room temperature for 1 day with subsequent dilution with water. The precipitate was filtered, washed with water and air-dried at $70{ }^{\circ} \mathrm{C}$, dissolved in methylene chloride and purified on silica gel (L 100/250), eluting with methylene chloride. The eluate was evaporated and the porphyrin was precipitated with methanol. The precipitate was filtered, washed with methanol and dried. Yield: $8.2 \mathrm{mg}(13.4 \%)$. Method $B$ (from acid). A solution of $50 \mathrm{mg}(0.033 \mathrm{mmol})$ of $22,14.5 \mathrm{mg}(0.119 \mathrm{mmol})$ of DMAP and $25 \mathrm{mg}(0.121 \mathrm{mmol})$ of EDAC in $25 \mathrm{~mL}$ of THF was stirred at $0{ }^{\circ} \mathrm{C}$ for $1 \mathrm{~h}$, then $45 \mathrm{mg}(0.166 \mathrm{mmol})$ of cholesterol was introduced and the mixture was stirred at the same temperature for $30 \mathrm{~min}$. Further stirring at ambient temperature was performed for several days until the reaction was complete. The mixture was purified on c silica gel (L 100/250), eluting with methylene chloride. The eluate was evaporated and the porphyrin was precipitated with methanol. The precipitate was filtered, washed with methanol and dried. Yield: $20 \mathrm{mg}$ (32.3\%). A similar synthesis in methylene chloride afforded $4.9 \mathrm{mg}(7.8 \%)$ of the porphyrin. $\mathrm{R}_{\mathrm{f}}=0.59$ (benzene). EAS $\lambda_{\max }$ (lge): 650 (3.48); 594 (3.48); 557 (3.70); 519 (3.83); 422 (5.24). IR $\mathrm{cm}^{-1}: v_{\text {OCO }}-1743 .{ }^{1} \mathrm{H}$ NMR $\delta$ ppm: $8.89 \mathrm{~s}(8 \mathrm{H}, \beta-\mathrm{H}) ; 8.10-8.18 \mathrm{~m}(8 \mathrm{H}, 2.6-\mathrm{H}-\mathrm{Ar}) ; 7.26-$ $7.35 \mathrm{~m}(8 \mathrm{H}, 3.5-\mathrm{H}-\mathrm{Ar}) ; 4.33-4.44 \mathrm{~m}\left(8 \mathrm{H}, \mathrm{OCH}_{2}\right) ; 2.43-2.54 \mathrm{~m}(2 \mathrm{H}$, $\left.\mathrm{COCH}_{2}\right) ;-2.74$ bs $(2 \mathrm{H}, \mathrm{NH}) ; 0.6-2.10$ (a series of resonance signals of alkyl chains and cholesterol residue).

Dimeric porphyrin (24). A solution of $50 \mathrm{mg}(0.033 \mathrm{mmol})$ of 5-[4-(10-carboxydecamethyleneoxy)phenyl]-10,15,20-tris(4hexadecyloxyphenyl)porphine $\mathbf{2 2}, 24 \mathrm{mg}(0.116 \mathrm{mmol})$ of EDAC and $14 \mathrm{mg}(0.115 \mathrm{mmol})$ of DMAP in $20 \mathrm{~mL}$ of methylene chloride was cooled in a water bath to $0{ }^{\circ} \mathrm{C}$ and then stirred for $1 \mathrm{~h}$ followed by the addition of solution of 5-(4-aminophenyl)-10,15,20triphenylporphine $23(24.5 \mathrm{mg}, 0.039 \mathrm{mmol})^{[2]}$ in $5 \mathrm{~mL}$ of methylene chloride. The mixture was stirred at ambient temperature for $24 \mathrm{~h}$ and then refluxed while protected with a calcium chloride tube for 1day. The dimer was purified by chromatography on silica gel (L 100/250), eluting with methylene chloride. The eluate was evaporated and the dimeric porphyrin was precipitated with 
methanol. The precipitate was filtered, washed with methanol and dried. Yield: $24.5 \mathrm{mg}(35.1 \%) . \mathrm{R}_{\mathrm{f}}=0.21$ (benzene). EAS $\lambda_{\text {max }}(\lg \varepsilon)$ : 649 (4.23); 592 (4.26); 554 (4.45); 517 (4.65); 420 (6.03). IR cm 1606. ${ }^{1} \mathrm{H}$ NMR $\delta$ ppm: $8.83-8.95 \mathrm{~m}(16 \mathrm{H}, \beta-\mathrm{H}) ; 8.19-8.28 \mathrm{~m}(6 \mathrm{H}$, 2.6-H-Ph); 8.07-8.17 m (10H, 2.6-H-Ar); 7.71-7.86 m (9H, 3.4.5-H$\mathrm{Ph}) ; 7.35$ bs (1H, NHCO); 7.22-7.34 m (10H, 3.5-H-Ar); 4.19-4.32 $\mathrm{m}\left(8 \mathrm{H}, \mathrm{OCH}_{2}\right) ; 2.53 \mathrm{t}\left(2 \mathrm{H}, J=7.0 \mathrm{~Hz}, \mathrm{CH}_{2} \mathrm{CO}\right) ; 1.88-2.08 \mathrm{~m}(10 \mathrm{H}$, $\left.\mathrm{CH}_{2}\right) ; 1.59-1.74 \mathrm{~m}\left(10 \mathrm{H}, \mathrm{CH}_{2}\right) ; 1.24-1.46 \mathrm{~m}\left(90 \mathrm{H}, \mathrm{CH}_{2}\right) ; 0.88-0.96$ $\mathrm{m}\left(9 \mathrm{H}, \mathrm{CH}_{3}\right) ;-2.70 \mathrm{bs},-2.74$ bs $(2 \times 2 \mathrm{H}, \mathrm{NH})$.

5,10,15,20-Tetrakis(4-propyloxycarbonylphenyl)porphine (25, para-, $\left.\mathrm{R}=-\left(\mathrm{CH}_{2}\right)_{2} \mathrm{CH}_{3}\right)$. A mixture of $50 \mathrm{mg}(0.063 \mathrm{mmol})$ of 5,10,15,20-tetrakis(4-carboxyphenyl)porphine 11 (para), $0.5 \mathrm{~mL}$ (6.7 mmol) of propyl alcohol, $33 \mathrm{mg}(0.271 \mathrm{mmol})$ of DMAP and $100 \mathrm{mg}(0.522 \mathrm{mmol})$ of EDAC was dissolved in $15 \mathrm{~mL}$ of methylene chloride and stirred at $0{ }^{\circ} \mathrm{C}$ in for $1.5 \mathrm{~h}$, then at ambient temperature for 5 days. The porphyrin was isolated by chromatography on silica gel (L 100/250), eluting with methylene chloride. The eluate was evaporated and the porphyrin was precipitated with methanol. The precipitate was filtered, washed with methanol and dried. Yield: $15.9 \mathrm{mg}(26.2 \%) . \mathrm{R}_{\mathrm{f}}=0.22$ (benzene). EAS $\lambda_{\max } \mathrm{nm}$ (lge): 647 (3.81); 591 (3.95); 551 (4.09); 516 (4.38); 421 (5.73). IR cm ${ }^{-1}: v_{\text {OCO }}-1718 .{ }^{1} \mathrm{H}$ NMR $\delta \mathrm{ppm}: 8.83 \mathrm{~s}$ $(8 \mathrm{H}, \beta-\mathrm{H}) ; 8.44 \mathrm{~d}(8 \mathrm{H}, J=8.0 \mathrm{~Hz}, 2.6-\mathrm{H}-\mathrm{Ar}) ; 8.31 \mathrm{~d}(8 \mathrm{H}, J=8.0 \mathrm{~Hz}$, 3.5 -H-Ar); $4.53 \mathrm{t}\left(8 \mathrm{H},{ }^{1} J=6.7 \mathrm{~Hz}, \mathrm{OCH}_{2}\right) ; 1.93 \mathrm{sc}\left(8 \mathrm{H},{ }^{1} J=6.7 \mathrm{~Hz}\right.$, $\left.\mathrm{CH}_{2}\right) ; 1.25 \mathrm{t}\left(12 \mathrm{H},{ }^{1} J=6.7 \mathrm{~Hz}, \mathrm{CH}_{3}\right) ;-2.76$ bs $(2 \mathrm{H}, \mathrm{NH})$.

5,10,15,20-Tetrakis(4-n-butyloxycarbonylphenyl)porphine (25, para-, $\left.\mathrm{R}=-\left(\mathrm{CH}_{2}\right)_{3} \mathrm{CH}_{3}\right)$ was obtained in a similar manner as described for 5,10,15,20-tetrakis(4-propyloxycarbonylphenyl) porphine. Yield: $26.2 \% . \mathrm{R}_{\mathrm{f}}=0.30$ (benzene). EAS $\lambda_{\max } \mathrm{nm}(\lg \varepsilon)$ : 647 (3.77); 591 (3.90); 551 (4.04); 516 (4.33); 421 (5.68). IR cm-1. $v_{\mathrm{OCO}}-1718$. ${ }^{1} \mathrm{H}$ NMR $\delta \mathrm{ppm}: 8.85 \mathrm{~s}(8 \mathrm{H}, \beta-\mathrm{H}) ; 8.43 \mathrm{~d}(8 \mathrm{H}, J=7.9 \mathrm{~Hz}$, 2.6-H-Ar); $8.32 \mathrm{~d}(8 \mathrm{H}, J=7.9 \mathrm{~Hz}, 3.5-\mathrm{H}-\mathrm{Ar}) ; 4.53 \mathrm{t}\left(8 \mathrm{H},{ }^{1} J=6.8 \mathrm{~Hz}\right.$, $\left.\mathrm{OCH}_{2}\right) ; 1.94 \mathrm{qv}\left(8 \mathrm{H},{ }^{1} \mathrm{~J}=6.8 \mathrm{~Hz}, \mathrm{CH}_{2}\right) ; 1.58 \mathrm{sc}\left(8 \mathrm{H}, \mathrm{CH}_{2}\right) ; 1.12 \mathrm{t}$ $\left(12 \mathrm{H},{ }^{1} J=6.8 \mathrm{~Hz}, \mathrm{CH}_{3}\right) ;-2.78$ bs $(2 \mathrm{H}, \mathrm{NH})$.

5,10,15,20-Tetra(4-n-hexyloxycarbonylphenyl)porphine (25, para-, $\left.\mathrm{R}=-\left(\mathrm{CH}_{2}\right)_{5} \mathrm{CH}_{3}\right)$. A mixture of $0.4 \mathrm{~g}(0.5 \mathrm{mmol}) 11$ (para-), $1.0 \mathrm{~g}(7.24 \mathrm{mmol})$ potash and $2.0 \mathrm{~mL}(13.60 \mathrm{mmol})$ hexyl iodide in $20 \mathrm{~mL}$ DMF was refluxed for $12 \mathrm{~h}$, then poured into $200 \mathrm{~mL}$ of water, the precipitate was filtered, washed with water and dried at $70{ }^{\circ} \mathrm{C}$. The precipitate was dissolved in methylene chloride, filtered, evaporated and chromatographed on silica gel (L 100/250), the eluate was evaporated and the porphyrin was precipitated with methanol, filtered and dried at ambient temperature in air. Yield: $0.13 \mathrm{~g}(23.1 \%) . \mathrm{R}_{\mathrm{f}}=0.31$ (benzene). EAS $\lambda_{\text {max }} \mathrm{nm}(\lg \varepsilon): 647$ (3.80); 590 (3.93); 552 (4.06); 516 (4.35); 421 (5.69). IR cm ${ }^{-1}: v_{\text {OCO }}-1719$. ${ }^{1} \mathrm{H}$ NMR $\delta$ ppm: $8.86 \mathrm{~s}(8 \mathrm{H}, \beta-\mathrm{H}) ; 8.48 \mathrm{~d}(8 \mathrm{H}, J=7.9 \mathrm{~Hz}, 2.6-\mathrm{H}-\mathrm{Ar})$; $8.35 \mathrm{~d}(8 \mathrm{H}, J=7.9 \mathrm{~Hz}, 3.5-\mathrm{H}-\mathrm{Ar}) ; 4.52 \mathrm{t}\left(8 \mathrm{H},{ }^{1} J=7.0 \mathrm{~Hz}, \mathrm{OCH}_{2}\right)$; $1.96 \mathrm{qv}\left(8 \mathrm{H},{ }^{1} \mathrm{~J}=7.0 \mathrm{~Hz}, \mathrm{CH}_{2}\right) ; 1.56-1.66 \mathrm{~m}\left(8 \mathrm{H}, \mathrm{CH}_{2}\right) ; 1.41-1.50 \mathrm{~m}$ $\left(8 \mathrm{H}, \mathrm{CH}_{2}\right) ; 1.19-1.43 \mathrm{~m}\left(8 \mathrm{H}, \mathrm{CH}_{2}\right) ; 0.98 \mathrm{t}\left(12 \mathrm{H},{ }^{1} \mathrm{~J}=7.0 \mathrm{~Hz}, \mathrm{CH}_{3}\right)$; -2.78 bs $(2 \mathrm{H}, \mathrm{NH})$.

5,10,15,20-Tetrakis(4-n-heptyloxycarbonylphenyl)porphine (25, para-, $\left.\mathrm{R}=-\left(\mathrm{CH}_{2}\right)_{6} \mathrm{CH}_{3}\right)$. Yield $22.4 \% . \mathrm{R}_{\mathrm{f}}=0.48$ (benzene). EAS $\lambda_{\text {max }}$ nm (lge): 647 (3.81); 590 (3.94); 551 (4.07); 516 (4.36); 421 (5.70). IR cm ${ }^{-1}: v_{\text {OCO }}-1717 .{ }^{1} \mathrm{H}$ NMR $\delta$ ppm: $8.85 \mathrm{~s}(8 \mathrm{H}, \beta-\mathrm{H})$; $8.49 \mathrm{~d}(8 \mathrm{H}, J=7.9 \mathrm{~Hz}, 2.6-\mathrm{H}-\mathrm{Ar}) ; 8.33 \mathrm{~d}(8 \mathrm{H}, J=7.9 \mathrm{~Hz}, 3.5-\mathrm{H}-\mathrm{Ar})$; $4.55 \mathrm{t}\left(8 \mathrm{H},{ }^{1} \mathrm{~J}=6.7 \mathrm{~Hz}, \mathrm{OCH}_{2}\right) ; 1.93 \mathrm{qv}\left(8 \mathrm{H},{ }^{1} \mathrm{~J}=6.7 \mathrm{~Hz}, \mathrm{CH}_{2}\right) ; 1.54-$ $1.60 \mathrm{~m}\left(8 \mathrm{H}, \mathrm{CH}_{2}\right) ; 1.40-1.50 \mathrm{~m}\left(8 \mathrm{H}, \mathrm{CH}_{2}\right) ; 1.20-1.45 \mathrm{~m}\left(16 \mathrm{H}, \mathrm{CH}_{2}\right)$; $0.92 \mathrm{t}\left(12 \mathrm{H},{ }^{1} \mathrm{~J}=6.7 \mathrm{~Hz}, \mathrm{CH}_{3}\right) ;-2.78$ bs $(2 \mathrm{H}, \mathrm{NH})$.

5,10,15,20-Tetra(4-n-hexadecyloxycarbonylphenyl)porphine (25, para-, $\left.\mathrm{R}=-\left(\mathrm{CH}_{2}\right)_{15} \mathrm{CH}_{3}\right)$. Method $\mathrm{A}$. A mixture of $50 \mathrm{mg}$ (0.063 mmol) of 5,10,15,20-tetrakis(4-carboxyphenyl)porphine $\mathbf{1 1}$ (para), $67 \mathrm{mg}(0.276 \mathrm{mmol})$ of cetyl alcohol, $19 \mathrm{mg}(0.156 \mathrm{mmol})$ of DMAP and $73 \mathrm{mg}(0.381 \mathrm{mmol})$ of EDAC was dissolved in $15 \mathrm{~mL}$ of methylene chloride and refluxed with the protection by a calcium chloride tube for $3 \mathrm{~h}$. The porphyrin was isolated by chromatography on silica gel (L 100/250), eluting with methylene chloride. The eluate was evaporated and the porphyrin was precipitated with methanol. The precipitate was filtered, washed with methanol and dried. Yield: $12.1 \mathrm{mg}(11.4 \%)$. Method B. A mixture of $0.2 \mathrm{~g}(0.25 \mathrm{mmol})$ of 11 (para), $1.0 \mathrm{~g}$ (7.2 mmol) of potash, $4.4 \mathrm{~g}(14.4 \mathrm{mmol})$ of hexadecyl bromide and $0.5 \mathrm{~g}$ of potassium iodide in $10 \mathrm{~mL}$ DMF was refluxed for $10 \mathrm{~h}$, then diluted with $100 \mathrm{~mL}$ of water, the precipitate was filtered, washed with water and dried at $70{ }^{\circ} \mathrm{C}$, dissolved in methylene chloride, filtered purified on silica gel eluting with methylene chloride, evaporated and precipitated with methanol. The precipitate was filtered, washed with methanol and dried in air at ambient temperature. Yield: $90 \mathrm{mg}(21.3 \%) . \mathrm{R}_{\mathrm{f}}=0.88$ (benzene). EAS $\lambda_{\max } \mathrm{nm}$ (lge): 646 (3.87); 590 (3.98); 550 (4.10); 516 (4.37); 420 (5.75). IR cm ${ }^{-1}: v_{\text {OCO }}$ 1720. ${ }^{1} \mathrm{H}$ NMR $\delta$ ppm: $8.84 \mathrm{~s}(8 \mathrm{H}, \beta-\mathrm{H}) ; 8.46 \mathrm{~d}(8 \mathrm{H}, J=7.9 \mathrm{~Hz}$, $2.6-\mathrm{H}-\mathrm{Ar}) ; 8.31 \mathrm{~d}(8 \mathrm{H}, J=7.9 \mathrm{~Hz}, 3.5-\mathrm{H}-\mathrm{Ar}) ; 4.53 \mathrm{t}\left(8 \mathrm{H},{ }^{1} J=6.7 \mathrm{~Hz}\right.$, $\left.\mathrm{OCH}_{2}\right) ; 1.94 \mathrm{qv}\left(8 \mathrm{H},{ }^{1} \mathrm{~J}=6.7 \mathrm{~Hz}, \mathrm{CH}_{2}\right) ; 1.54-1.63 \mathrm{~m}\left(8 \mathrm{H}, \mathrm{CH}_{2}\right) ; 1.43-$ $1.51 \mathrm{~m}\left(8 \mathrm{H}, \mathrm{CH}_{2}\right) ; 1.19-1.43 \mathrm{~m}\left(88 \mathrm{H}, \mathrm{CH}_{2}\right) ; 0.87 \mathrm{t}\left(12 \mathrm{H},{ }^{1} J=6.7 \mathrm{~Hz}\right.$, $\left.\mathrm{CH}_{3}\right) ;-2.78$ bs $(2 \mathrm{H}, \mathrm{NH})$.

5,10,15,20-Tetrakis [4-(perfluoro-1,1,3-H-propyloxycarbonyl)phenyl]porphine (25, para-, $\mathrm{R}=\mathrm{CH}_{2} \mathrm{CF}_{2} \mathrm{CF}_{2} \mathrm{H}$ ). The compound was obtained similarly to the porphyrin 25 (para-, $\left.\mathrm{R}=-\left(\mathrm{CH}_{2}\right)_{2} \mathrm{CH}_{3}\right)$, using $0.5 \mathrm{~mL}(5.5 \mathrm{mmol})$ of $n$-perfluoro-1,1,3- $H$ propyl alcohol. The reaction time was 2 days. Yield: $51 \mathrm{mg}(64.8$ \%). $\mathrm{R}_{\mathrm{f}}=0.72$ (benzene). EAS $\lambda_{\max } \mathrm{nm}(\lg \varepsilon): 647$ (3.77); 591 (3.91); 551 (4.04); 516 (4.35); 421 (5.68). IR cm ${ }^{-1}: v_{\mathrm{OCO}}-1734 ; v_{\mathrm{CF}}-1273$. ${ }^{1} \mathrm{H}$ NMR $\delta$ ppm: $8.86 \mathrm{~s}(8 \mathrm{H}, \beta-\mathrm{H}) ; 8.51 \mathrm{~d}(8 \mathrm{H}, J=8.2 \mathrm{~Hz}, 2.6-\mathrm{H}-\mathrm{Ar})$; $8.38 \mathrm{~d}(8 \mathrm{H}, J=8.2 \mathrm{~Hz}, 3.5-\mathrm{H}-\mathrm{Ar}) ; 6.11 \mathrm{tt}\left(4 \mathrm{H},{ }^{1} J=51.9 \mathrm{~Hz},{ }^{2} J=5.1\right.$ $\left.\mathrm{Hz}, \mathrm{CHF}_{2}\right) ; 5.06 \mathrm{t}\left(8 \mathrm{H} .3 \mathrm{~J}=13.3 \mathrm{~Hz}, \mathrm{OCH}_{2}\right) ;-2.78 \mathrm{~s}(2 \mathrm{H}, \mathrm{NH})$.

5,10,15,20-Tetrakis [4-(perfluoro-1,1,9-H-nonyloxycarbonyl) phenyl]porphine (25, para-, $\left.\mathrm{R}=\mathrm{CH}_{2}\left(\mathrm{CF}_{2}\right)_{7} \mathrm{CF}_{2} \mathrm{H}\right)$. Method $\mathrm{A}$. A mixture of $100 \mathrm{mg}(0.126 \mathrm{mmol})$ of $5,10,15,20$-tetrakis(4carboxyphenyl)porphyrine 11 (para), $470 \mathrm{mg}$ (1.088 mmol) of $n$-perfluoro-1,1,9- $H$-nonyl alcohol, $67 \mathrm{mg}(0.548 \mathrm{mmol})$ of DMAP and $200 \mathrm{mg}(1.043 \mathrm{mmol})$ of EDAC was dissolved in $25 \mathrm{~mL}$ of anhydrous methylene chloride and stirred at $0{ }^{\circ} \mathrm{C}$ for $1.5 \mathrm{~h}$, then at ambient temperature until completion of the reaction (2 days, TLC). The porphyrin was isolated by chromatography on silica gel (L 100/250), eluting with methylene chloride. The eluate was evaporated and the product was precipitated with methanol. The precipitate was filtered, washed with methanol and dried. Yield: $84 \mathrm{mg}(27.2 \%)$. Method B. A mixture of $100 \mathrm{mg}(0.126 \mathrm{mmol})$ of $\mathbf{1 1}$ (para) with $30 \mathrm{~mL}$ of methylene chloride was subjected to ultrasound for $1 \mathrm{~h}$. Then $250 \mathrm{mg}(0.579 \mathrm{mmol})$ of $n$-perfluorononyl-1,1,9-H-nonyl alcohol, $37 \mathrm{mg}(0.301 \mathrm{mmol})$ of DMAP and $150 \mathrm{mg}(0.782 \mathrm{mmol})$ of EDAC were added to the suspension and it was stirred at $0{ }^{\circ} \mathrm{C}$ for $1.5 \mathrm{~h}$, then at ambient temperature until completion of the reaction (4 days, TLC). The mixture was purified on silica gel (L 100/250), eluting with methylene chloride. The eluate was evaporated, the porphyrin was precipitated with methanol. The precipitate was filtered, washed with methanol and dried. Yield: $105 \mathrm{mg}(33.0 \%) . \mathrm{R}_{\mathrm{f}}=0.80$ (benzene). EAS $\lambda_{\max } \mathrm{nm}(\lg \varepsilon): 648$ (3.84); 591 (3.96); 551 (4.08); 516 (4.37); 421 (5.67). IR cm ${ }^{-1}: v_{\text {oco }}$ $1738 ; v_{\mathrm{CF}}-1211 .{ }^{1} \mathrm{H}$ NMR $\delta \mathrm{ppm}: 8.85 \mathrm{~s}(8 \mathrm{H}, \beta-\mathrm{H}) ; 8.50 \mathrm{~d}(8 \mathrm{H}$, $J=8.0 \mathrm{~Hz}, 2.6-\mathrm{H}-\mathrm{Ar}) ; 8.38 \mathrm{~d}(8 \mathrm{H}, J=8.0 \mathrm{~Hz}, 2.6-\mathrm{H}-\mathrm{Ar}) ; 6.10 \mathrm{tt}(4 \mathrm{H}$, $\left.{ }^{1} J=52.0 \mathrm{~Hz},{ }^{2} J=5.1 \mathrm{~Hz}, \mathrm{CHF}_{2}\right) ; 5.05 \mathrm{t}\left(8 \mathrm{H},{ }^{3} \mathrm{~J}=13.3 \mathrm{~Hz}, \mathrm{OCH}_{2}\right)$; -2.79 bs $(2 \mathrm{H}, \mathrm{NH})$.

5,10,15,20-Tetrakis[3-(perfluoro-1.1.9-H-nonyloxycarbonyl) phenyl]porphine (25, meta-, $\left.\mathrm{R}=\mathrm{CH}_{2}\left(\mathrm{CF}_{2}\right)_{7} \mathrm{CF}_{2} \mathrm{H}\right)$ was obtained similarly to 23 ( para-, $\mathrm{R}=\mathrm{CH}_{2}\left(\mathrm{CF}_{2}\right)_{7} \mathrm{CF}_{2} \mathrm{H}$ ) by the method $B$ using porphyrin 11 (meta). Reaction time was 5 days. Yield: $78 \mathrm{mg}$ $(25.2 \%) . \mathrm{R}_{\mathrm{f}}=0.77$ (benzene). EAS $\lambda_{\max } \mathrm{nm}(\lg \varepsilon): 649$ (3.91); 589 (3.93); 548 (3.99); 515 (4.37); 420 (5.72). IR cm $\mathrm{cm}^{-1}: v_{\mathrm{OCO}}-1741 ; v_{\mathrm{CF}}$ - 1210. ${ }^{1} \mathrm{H}$ NMR $\delta$ ppm: $9.28 \mathrm{~s}(4 \mathrm{H}, 2-\mathrm{H}-\mathrm{Ar}) ; 8.81-8.88 \mathrm{~m}(4 \mathrm{H}, 6-\mathrm{H}-$ Ar); $8.73 \mathrm{~s} ; 8.75 \mathrm{~s}(12 \mathrm{H}, 4-\mathrm{H}-\mathrm{Ar}+\beta-\mathrm{H}) ; 8.21 \mathrm{t}(4 \mathrm{H}, J=7.5 \mathrm{~Hz} ; 5-\mathrm{H}-$ $\mathrm{Ar}) ; 6.05 \mathrm{t}\left(4 \mathrm{H},{ }^{1} \mathrm{~J}=52 \mathrm{~Hz} ; \mathrm{CHF}_{2}\right) ; 5.10 \mathrm{t}\left(8 \mathrm{H},{ }^{2} \mathrm{~J}=16.4 \mathrm{~Hz}, \mathrm{OCH}_{2}\right)$; -0.76 bs $(4 \mathrm{H}, \mathrm{NH})\left(\mathrm{CDCl}_{3}-\mathrm{TFA}\right)$.

Acknowledgments. The current research was conducted in accordance with the State assignment of the Ministry of Science of Russian Federation. The porphyrinic compounds 
were synthesized with the support of Russian Foundation for Basic Research, project number 14-23-00204.

\section{References}

1. Salnikova M.A., Lubimova T.V., Glazunov A.V., Syrbu S.A., Semeikin A.S., Koifman O.I. Macroheterocycles 2013, 6, 53-58.

2. Salnikova M.A., Lubimova T.V., Glazunov A.V., Syrbu S.A., Semeikin A.S. Macroheterocycles 2014, 7, 249-255.

3. Salnikova M.A., Prigorelov G.A., Syrbu S.A., Golubchikov O.A., Semeikin A.S. Izv. Vyssh. Uchebn. Zaved., Khim. Khim. Tekhnol. 2013, 56, 38-41 (in Russ.).

4. Li Y., Cao L., Tian H. J. Org. Chem. 2006, 71, 8279-8282.

5. Maligaspe E., Tkachenko N.V., Subbaiyan N.K., et al. J. Phys. Chem. A 2009, 113, 8478-8489.

6. Sobral A.J.F.N., Melo S.M., Ramos M.L., Teixeira R., Andrade S.M., Costa S.M.B. Tetrahedron Lett. 2007, 48, 3145-3149.

7. Wu Z.-Q., Shao X.-B., Li C., Hou J.-L., Wang K., Jiang X.-K., Li Z.-T. J. Am. Chem. Soc. 2005, 127, 17460-17468.

8. Bakleh M.E., Sol V., Estieu-Gionnet K. Tetrahedron 2009, 65, 7385-7392.

9. Xiao Z.-Y., Hou J.-L., Jiang X.-K. Tetrahedron 2009, 65, 10182-10191.
10. Stasio B.D., Frochot C., Dumas D., Even P., Zwier J., Muller A., Didelon J., Guillemin F., Viriot M.-L., Barberi-Heyob M. Eur. J. Med. Chem. 2005, 40, 1111-1122.

11. Lebedev A.Y., Cheprakov A.V., Sakadžić S., Boas D.A., Wilson D.F., Vinogradov S.A. Appl. Mater. Interfaces 2009, 1, 1292-1304.

12. Burrell A.K., Officer D.L., Plieger P.G., Reid D.C.W. Chem. Rev. 2001, 101, 2751-2796.

13. Matsumoto J., Matsumoto T., Senda Y., Shiragami T., Yasuda M. J. Photochem. Photobiol., A 2008, 197, 101-109.

14. Han Z.-X., Luo H.-Y., Zhang X.-B., et al. Spectrochim. Acta: Part A 2009, 1084-1088.

15. Bakar M.B., Oelgemoller M., Senge M.O. Tetrahedron 2009, 65, 7064-7078.

16. Kolodina E.A., Lubimova T.V., Syrbu S.A., Semeikin A.S. Macroheterocycles 2009, 2, 33-41.

17. Kolodina E.A., Syrbu S.A., Semeikin A.S., Koifman O.I. Zh. Org. Khim. 2010, 46, 136-141 (in Russ.).

18. Mikhalitsyna E.A., Tyurin V.S., Nefedov S.E., Syrbu S.A., Semeikin A.S., Koifman O.I., Beletskaya I.P. Eur. J. Inorg. Chem. 2012, 5979-5990.

19. In: Organikum (transl. from Germ.), Moscow: BINOM, 2008, 2, p. 361-392 (in Russ.) [В кн.:Органикум (пер. с нем.), М.: Бином, 2008, с. 361-392]. 